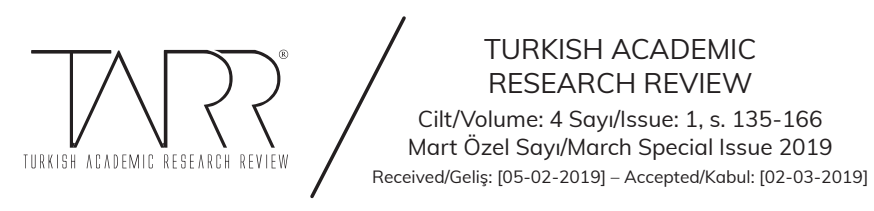

\title{
Bir Aidiyet Tartışması: Süleyman Hilmi Tunahan ve Muhammed İhsan Oğuz Arasında Üç Kitap*
}

Tunahan Erdoğan ${ }^{1}$

\section{Özet}

Yakın tarihimizde birisi talebe yetiştirme (tedrîs), diğeri eser yazma (telif) yönüyle temayüz etmiş iki önemli isme, içerikleri neredeyse birebir aynı olan üç eser, birlikte nispet edilmektedir: Süleyman Hilmi Tunahan ve Muhammed İhsan Oğuz. Mektuplar ve Bazı Mesâil-i Mühimme ve Risâle-i Kibrît-i Ahmer isimleri ile Süleymanlı Cemaatinin basıp "tekâmül” adı verilen eğitim sisteminden mezun olanlara hediye ettiği, cemaat içi sohbetler ve okumalarda bir tür rehber işlevi gören iki eser, Oğuz Yayınları tarafından da Muhammed İhsan Oğuz adına basılarak yayımlanmıștır. Risâle-i İksîr-i Ulûm ve Ma'rifet ise Oğuz Yayınları tarafından henüz basılmamış olmakla birlikte Oğuz'un bu isimde bir eserinin ellerinde bulunduğu varisleri ve Oğuz Vakfı yöneticileri tarafından belirtilmektedir. Bu makale, muhtevalarında yer alan bazı ifadelerden ve metin dışı çok sayıda unsurdan yararlanarak söz konusu eserlerin iki isimden hangisine ait olduğunu tespit etmeyi amaçlamaktadır. Araştırmalarımız neticesinde, eserlerin Oğuz’a ait olduğu ve muhtemelen sehven Tunahan'a izafe edildiği sonucuna ulaşılmıştır.

Anahtar Kelimeler: Süleyman Hilmi Tunahan, Muhammed İhsan Oğuz, Mektuplar, Mektuplar Risâlesi, Risâle-i Kibrît-i Ahmer, Risâle-i İksîr-i Ulûm ve Ma'rifet.

\section{A Disagreement of Ownership: Three Books Between Sulayman Hilmi Tunahan and Muhammed İhsan Oğuz}

\section{Abstract}

Sulayman Hilmi Tunahan and Muhammad Ihsan Oghuz are two important figures and have become distinguished in the aspects of training student (tadrîs) and

* Bu makale, 12-14 Ekim 2018 tarihinde Antalya'da düzenlenen Türk Akademik Araştırmalar Dergisi Uluslararas1 Multidisipliner Kongresi'nde "Mektuplar ve Bazı Mesâil-i Mühimme İsimli Eser ile Risâle-i Kibrît-i Ahmer ve Risâle-i İksîr-i Ulûm ve Ma'rifet'in Birlikte Basıldığı Kitapçık Kime Ait: Süleyman Hilmi Tunahan'a mı, Muhammed İhsan Oğuz'a mı?” başlığı ile sunulan ve özeti yayınlanan tebliğin gözden geçirilerek genişletilmiş halidir.

1 Araştırma Görevlisi, Akdeniz Üniversitesi, İlahiyat Fakültesi, Antalya, https://orcid.org/0000-00033374-6063, tunahanerdogan1234@hotmail.com. 
writing works (talif) respectively. In our recent history, almost identical three works have been attributed to both of them. The works, which are called as Mektuplar ve Bazı Mesâil-i Mühimme (The Letters and the Different Kind of Important Subjects) and Risâla-i Kibrît-i Ahmar are published by both Sulaimanian Group and Oghuz Puplications in the name of Sulayman Hilmi Tunahan and Muhammad Ihsan Oghuz respectively. Also, these works are used by the community of Sulaimanian in their conservation, readings and education system as a gift to the students who have graduated from their educational institutions. Although Risâla-i Iksîr-i Ulûm we Ma'rifat have not been published by Oghuz Publications yet, the administrators of Oghuz Foundation and Oghuz's heir have claimed that this work is in their hands. This article aims to determine that the works belong to whom we mentioned by taking advantage of some of the expressions in their texts and numerous factors outside of the text. As a result of our research, we came to conclusion that the works belong to Oghuz and probably these works were attributed to Tunahan wrongly.

Keywords: Süleyman Hilmi Tunahan, Muhammad Ihsan Oghuz, The Letters, Risâla of The Letters, Risâla-i Kibrît-i Ahmar, Risâla-i Iksîr-i Ulûm we Ma'rifat.

\section{Giriş}

Süleyman Hilmi Tunahan (1888-1959) ve Muhammed İhsan Oğuz (18871991) XIX. yüzyıl sonlarında dünyaya gelmiş, eğitimlerini Osmanlı döneminde tamamlayıp Cumhuriyetin kuruluşuna da tanıklık etmiş yakın tarihimizin iki önemli ismidir. Tunahan, medreselerin kapatılmasından sonra ortaya çıan dinî eğitim boşluğunu doldurmak için ömrünü talebe yetiştirmeye ve dinî ilimleri tedrîse adamıştır. ${ }^{2}$ Oğuz ise dinî ilimler alanında ve özellikle tasavvuf sahasında telif ile meşgul olmuştur. ${ }^{3}$ Her ikisi de Nakşî şeyhi olan ve hayatlarında iken birbirleri ile görüştükleri tespit edilemeyen bu iki ismi aynı makalede buluşturan şey ise Mektuplar ve Bazı Mesâili Mühimme, Risâle-i Kibrît-i Ahmer, Risâle-i İksîr-i Ulûm ve Ma'rifet isimleriyle Tunahan'in sevenleri tarafından basılan ve sahiplenilen üç eserin, Oğuz'un sevenleri tarafından da onun adına basılmış ve sahiplenilmiş olmasidır. ${ }^{4}$

Süleymanlı cemaati ${ }^{5}$ tarafından Süleyman Hilmi Tunahan'a nispet edilen Mektuplar ve Bazı Mesâili Mühimme isimli kitap 183 sayfadan oluşan, üzerinde basım yeri

2 Hayatı hakkında bilgi için bkz. Reşat Öngören, "Tunahan, Süleyman Hilmi”, Türkiye Diyanet Vakfi İslâm Ansiklopedisi, (İstanbul: TDV Yay., 2012), 41: 375-377.

3 Hayatı hakkında bilgi için bkz. Abdurrahman Memiş, "Oğuz, Muhammet İhsan", Türkiye Diyanet Vakfi İslâm Ansiklopedisi, (İstanbul: TDV Yay., 2007), 33: 321-322.

4 Risâle-i İksîr-i Ulûm ve Ma'rifet Oğuz Vakfı tarafından henüz basılmamış olmakla birlikte Oğuz'un yayıma hazırlanan eserleri arasında bu isimde bir eser mevcuttur.

5 Süleyman Hilmi Tunahan'ın sevenleri ve müntesipleri kendileri hakkında "Süleymanc1" tabirinin kullanılmasından hoşlanmadıkları (Fazilet Neşriyat Araştırma Heyeti, Silsiletü'z-Zeheb Silsile-i Sâdât-ı Nakşibendiyye, 5. bs., İstanbul: Fazilet Neşriyat, 2017, 352; Şaban Sitem Bölükbaş1, "Süleyman Efendi Cemaati", Türkiye Diyanet Vakfi İslâm Ansiklopedisi, (İstanbul: TDV Yay., 2012), 41: 377) ve "Süleymanlı" tabirinin kullanılmasını daha uygun buldukları için makale boyunca bu ifadenin kullanılması tercih edilmiştir.

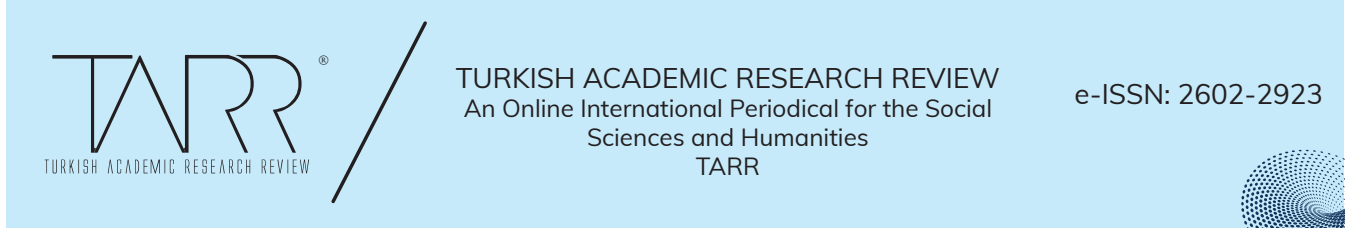


ve tarihi bulunmayan Osmanlı Türkçesi ile basılmış bir eserdir. Kapağında "Bu(nu yazan), İmâm-1 Rabbânînin evlâdından Salâhuddîn İbn Mevlânâ Sirâcüddîn'dir” ya da “Bu(nu yazan), İmâm-1 Rabbânî (ve) Salâhuddîn İbn Mevlânâ Sirâcüddîn'in evlâdından birisidir" anlamlarına gelebilecek "Hâzâ min evlâdi'l-İmâm er-Rabbânî Salâhuddîn İbn Mevlânâ Sirâcüddîn” şeklinde bir ifade bulunmaktadır. Kibrît-i Ahmer isimli risâle ise 22 sayfadan müteşekkildir. Bu risâlenin devamında 12 sayfalık Risâle-i İksîri Ulûm ve Ma'rifet isimli başka bir risâle daha bulunmaktadır. Her iki risâlenin de kapağında "Yazarına aittir" anlamına gelen "li muharririh" ifadesi mevcuttur. Basım tarihi hicrî 1330 (1912), basım yeri ise Şirket-i Mürettibiyye Matbaası olarak kayıtlıdır. Bu eserler cemaat içi sözlü nispetin yanı sıra bazı kaynaklarda da açıkça Süleyman Hilmi Tunahan'a nispet edilmektedir. Eserler, yalnızca cemaatin "tekâmül” adı verilen eğitim sisteminden mezun olanlara verilmekte ve cemaat içi sohbetlerde bir tür rehber vazifesi görmektedir. Oğuz Yayınları tarafından Muhammed İhsan Oğuz adına basılan Mektuplar ise 210 mektup ve iki ciltten oluşmaktadır. Sadeleştirilmiş hali ile birlikte orijinali de verilen mektupların ilk baskısı 1994'te yapılmıştır.

Bir metni, iki farklı kişinin aynı lafız ve ifadelerle kaleme almasının aklen ve âdeten imkânsız bir durum olduğu açıktır. Bu makale, adı geçen eserlerin muhtevalarını ve takipçilerine intikal süreçlerini göz önünde bulundurarak kime ait olduklarını tespit etmeye çalışmaktadır. Bu bağlamda öncelikle iki farklı kişiye nispet edilen eserler mukayese edilerek benzeşen ve ayrışan yönleri tespit edilmeye çalışılmıştır. Sonrasında metin içi ve metin dışı bilgiler yardımıyla mektupların kimlere yazıldığ 1 araştırılmış, içeriklerinde eserlerin kime ait olduğunu ortaya koyan ipuçları takip edilmiştir. Son olarak metinlerin bir taraftan diğerine nasıl, kim tarafından ve ne zaman intikal ettirildiği tespit edilmeye çalışılmıştır.

Araştırmamızda isimlerinin gizli kalmasını istedikleri için bilgi kaynaklarımızın bir kısmının isimlerine yer verilmemiştir. Bilgi aldığımız kişilerin isimleri tarafımızda mahfuz olup, söz konusu bilgiler de kayıt altındadır.

\section{Muhammed İhsan Oğuz Adına Basılan Mektuplar ile Süleyman Hilmi Tunahan'a Nispet Edilen Mektuplar'ın İçeriklerinin Mukayesesi}

Muhammed İhsan Oğuz'dan Mektuplar ismiyle Oğuz'a nispet edilen kitap ile Süleymanlı Cemaatinin basıp "tekâmül” adını verdiği sistemden mezun olan müntesiplere hediye ettiği Tunahan'a nispet edilen Mektuplar ve Bazı Mesâil-i Mühimme isimli eser üzerinde bir mukayese yapıldığında bazı farklılıklar dışında her iki metnin, tamamen örtüsstüğü gözlemlenmektedir. Söz konusu farklılıkları üç başlık altında toplamak mümkündür.

\subsection{Her İkisinde de Bulunduğu Halde Birinde Eksik ya da Fazla Olarak Yer Alan Mektuplar}

Tunahan'a nispet edilen Mektuplar'dan bazılarının baş taraflarında bulunan bir kısım ifadeler, Oğuz adına basılmış Mektuplar'da yer almamaktadır. Örneğin; Tu-

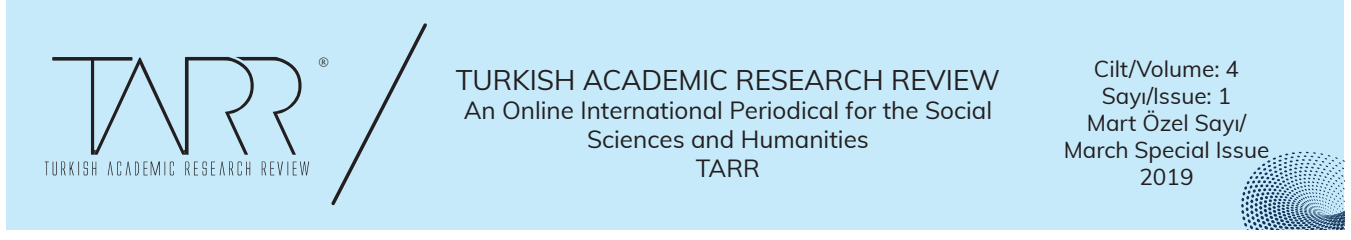


nahan'a nispet edilen Mektuplar'da “Müminler Ölmez - Hayât-1 Berzah” başlı̆ğ ile kaydedilen mektubun baş kısmında bulunan;

"Vâlide-i muhteremenizin dâr-1 âhirete intikali haberini müş'ir olan mektubunuzu bu sabah kemâl-i hüzn ile aldım. Pek fazla müteellim oldum. Hasbe'l-beşeriyye bu hadiseden müteessir ve müteellim olmamak mümkün değildir. Fakat bu teessür ve teellümü 'Küllü nefsin zâikatü'l-mevt sümme ileynâ türce'ûn' ve 'İnnâ lillâh ve innâ ileyhi râciûn' âyât-i celîlesinin ve 'el-Mü'minûne lâ yemûtûne bel yunkalûne min dârin ilâ dâr' ve 'el-mü'minü hayyun fî̀d-dâreyn' haberlerinin mutezammın oldukları manaları düşünerek ta'dîl etmek, belki tamamıyla izâle etmek lazımdır” (s. 109)

ifadeleri Oğuz’un Mektuplar'ında (I: 549) bulunmamaktadır. Bahsedilen kısmın Oğuz'un Mektuplar'ında bulunmamasının sebebi, Oğuz'un Mektuplar'ına dayanak teşkil eden Hayri Taptık' ${ }^{6}{ }^{6}$ mektupların asıllarından istinsah ettiği el yazması nüshada bu ifadelerin yer almamasıdır. Zira Hayri Taptık, Oğuz'un mektuplarını kaydederken "kütük" tabir edilen defterlere Mektuplar'ın baş kısımlarında bulunan şahsî ve özel bölümleri almamış, ilgisini mektupların muhtevasında bulunan bilgilerle sınırlı tutmuştur. Bu yüzden bu kısımlar Oğuz adına basılmış Mektuplar'a girememiştir. Bahsedilen durum, aynı zamanda Tunahan'a nispet edilen mektupların, Hayri Taptık'ın kütüğünden değil, mektupların asıllarından ya da asıllarından istinsah edilmiş diğer bir nüshadan bir başkası tarafından istinsah edildiğini göstermektedir. Yani Tunahan'a nispet edilen Mektuplar'ın, Oğuz'un mektuplarını kaydeden Hayri Taptık'ın defterlerine değil, mektupların asıllarına ya da asıllarından istinsah edilen başka bir nüshaya dayandığı anlaşılmaktadır.

Öte yandan bu mektubun Oğuz'un kitabında bulunan son paragrafı bu defa Tunahan'da bulunmamaktadır. Paragraf şu şekildedir:

"Ehl-i berzah, ehl-i dünyanın atıyyesine eşedd-i ihtiyaçla muhtaçtır, anlara vâki’ olacak ufak hediyyeler büyük memnuniyeti, imdadı müstelzim olur" (I: 550).

Benzer şekilde Oğuz'un 35 numaralı mektubunun baş kısmında bulunan

"Benimle mesbûk ve müesses olan münâsebât-1 mâzıyyeye ait mükteseb hukukunuz tamamiyle mahfûzdur. Cenâb-1 Hakk'ın; hilkat-i insâniyyeden maksûd olan ibâdet, ubûdiyyet, rızâ ve likâ-i zâtîsine mazhariyyet-i kâmileniz mütezarra'dır” (I: 435).

ifadeleri Tunahan'a nispet edilen Mektuplar'da “Temessük-ü Hakîkî” başlığı taşıyan mektubun (s. 22) baş kısmında bulunmamaktadır. Oğuz'un ilgili mektubunun sonunda tarih kaydi bulunmazken, Tunahan'in mektubunda miladi takvimde 10 Nisan 1923'e denk gelen 23 Şaban 1341 tarihi bulunmaktadır.

Oğuz'un kitabında "Nefs ve Mahabbet” başlığını taşıyan 156. mektup (II: 475) baş ve son taraflarından biraz eksik ile Tunahan'a nispet edilen Mektuplar'da “Zik-

6 Hayri Taptık, Muhammed İhsan Oğuz'un mektuplarının büyük kısmının aslını oluşturan ve "kütük" tabir edilen el yazması nüshaları, mektupların gönderildiği kişilerdeki asıllarından istinsah eden kişidir.




re Ait Maârif” başlığı ile yer almakta ve "Dört nevi zikir şunlardır” ifadesi ile başlamaktadır (s. 34). Oğuz'un kitabında ise "Sorduğunuz dört nevi zikir şunlardır" şeklindedir (II: 475).

Oğuz'un Mektuplar'ında “Hicr ve Mevt” başlı̆̆ını taşıyan 194 numaralı mektubun (II: 550) baş kısmından iki paragraf Tunahan'ın Mektuplar'ında bulunmamaktadir (s. 35). Tunahan'in Mektuplar'inda yalnızca bir paragraf olarak kaydedilen mektubun, Oğuz'un kitabında yer alan devamı da burada bulunmamaktadır.

Oğuz’un kitabında “İtminân-ı Kalb” başlığıyla kayıtlı 155. mektubun (II: 470) baş tarafından iki sayfalık kısım, Tunahan'a nispet edilen mektuplarda mevcut değildir (s. 56).

Oğuz'un 116 numaralı “Üç İctimâ' Tarîkat-i Sıddîkiyye’de Sülûk ve Vusûl Yolu” başlıklı mektubun (II: 396) baş kısmından iki sayfalık bölüm Tunahan'a nispet edilen Mektuplar'da mevcut değildir (s. 54). Ayrıca Tunahan'ın Mektuplar'inda ikinci paragrafın sonunda yer alan "Bu husûsât, tarz-1 diğerde bizim Kitâbü Âdâbi'l-Mürîd'imiz'de mezkûrdur” (s. 54) ifadeleri Oğuz'un ilgili paragrafının sonunda yer almamaktadir (II: 399).

İki metin arasındaki farklılıklar işaret ettiklerimiz ile sınırlı olmayıp, benzer şekilde başka bazı küçük farklılıklar da bulunmaktadır.

\subsection{Başlığı Farklı Olan Mektuplar}

Mektuplar'ın başlıklarında da bir kısım farklılıklar mevcuttur. Örneğin; her iki kitapta da ilk sırada yer alan mektup, Oğuz'un kitabında "Nispet ve Mahabbetin Şartları" başlığını taşımakta iken (I: 337) Tunahan'a nispet edilen baskıda "Sülûk için Maârif-i Aliyye” başlığını taşımaktadır (s. 9).

Oğuz'un kitabında "A’mâl-i Dîniyye ve Vazâif-i Taabbüdiyyenin İktitâf-1 Semerât1na Mâni' Olan Esbâb ve Avâmil-i Kesîre'nin Usûl ve Esâsât-1 Mühimmesi” başlığ1 ile yer alan mektup (I: 435), Tunahan'a nispet edilen Mektuplar'da “Temessük-i Hakîkî” başlığı altında verilmiştir (s. 22). Tunahan'a nispet edilen Mektuplar'a asıl teşkil eden ve bizim de elimizde fotokopisi bulunan el yazması nüshada ise ilgili mektupta herhangi bir başlık yer almamaktadır. Asıl nüshada başlık bulunmadığ halde baskıda yer alması, söz konusu başlığın, Mektuplar'ı baskıya hazırlayan kişi ya da kişiler tarafından eklendiğini, yani bu kişiler tarafından metin üzerinde bazı tasarruflarda bulunulduğunu göstermektedir. Nitekim Oğuz'un Mektuplar'ını baskıya hazırlayan Mustafa Bayburtlu, ${ }^{7}$ Oğuz'un oğlu Abdülhalik Muhammed Oğuz ve torunu Mehmet İhsan Oğuz ile yaptığımız görüşmede ${ }^{8}$ onlar da başlıkların

7 Mustafa Bayburtlu, Oğuz'un çok sayıda eserini baskıya hazırlamış ve sadeleştirmiştir. Eserler ile uzun süreli meşguliyetinin yanı sıra ilme olan merakı sebebiyle Oğuz'un kitaplarına derin vukufiyet sahibidir.

8 Oğuz'un oğlu Abdülhalik Muhammed Oğuz, torunu Mehmet İhsan Oğuz, sevenlerinden Mehmet Yaşar ile 19 Eylül 2018>de Kastamonu>da, Mektuplar 1-2 isimli kitapları sadeleştiren ve yayına hazırlayan Mustafa Bayburtlu ile 20-21 Eylül 2018 tarihinde Çorum'da görüşülmüştür. Bu mülakat dışında özellikle Mustafa Bayburtlu ile bilgi amaçlı çok sayıda telefon görüşmesi gerçekleştirilmiştir. Bayburtlu ile olan görüşmemiz Prof. Dr. Hayrettin Karaman'ın delalet ve tavassutu ile gerçekleşmiştir. Araştırmamız süresince bizden yardımlarını esirgemeyen Mustafa Bayburtlu başta olmak üzere isimlerini saydığımız ve sayamadığımız zatların hepsine teşekkürü borç biliriz.

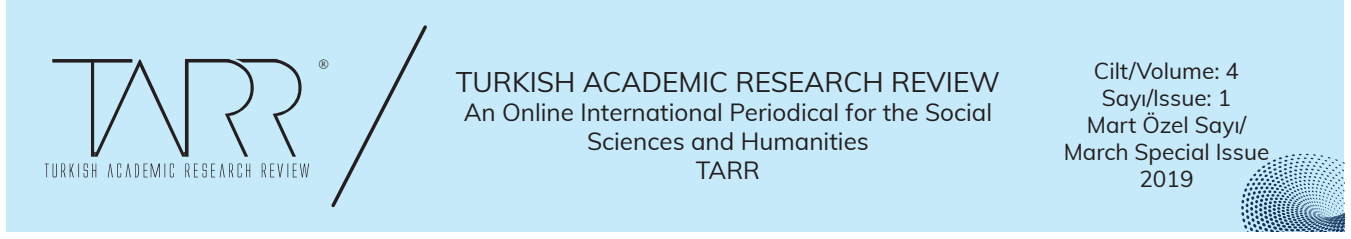


Hayri Taptık tarafından muhtevaya uygun biçimde konulduğunu ifade etmişlerdir. Bazı başlıklar ise Mektuplar'ı baskıya hazırlayan Mustafa Bayburtlu tarafından konulmuştur.

Oğuz'un 130 numaralı mektubu yalnızca “Mâsivallâha Giriftarlık” başlığını taşırken (II: 422) Tunahan'ın Mektuplar'ında ilgili mektup "Ef’âl ve İrâde-i Beşeriyye, Izdırârî ve İhtiyârî Ef'âl, Mâsivallâha Giriftarlık” başlığını taşımaktadır (s. 31).

Oğuz'un Mektuplar'ında “Hicr ve Mevt” başlığını taşıyan 194 numaralı mektup (II: s. 550) Tunahan'ın Mektuplar'ında “Mevt Bahsinden Bekâ-yı Rûh” şeklindedir (s. 35). Tunahan'ın mektuplarına asıl teşkil eden el yazması nüshada ise başlık yalnızca "Mevt Bahsinden" şeklindedir.

Oğuz'un 104 numaralı mektubu “Hazret-i Sıddîk’in Fezâil ve Hasâisi” başlığı ile verilmiştir (II: 374). Tunahan'ın kitabında ise aynı mektup "Fazl-1 Cenâb-1 Siddîk-i Ekber -radıyallâhu anh-” başlığı ile kayıtlıdır (s. 48).

Oğuz'un 119. mektubu "Kardeşlerin Mütekâbil Muhabbetleri ve Makâm-1 Mahbûbiyyet” başlı̆g 1 ile verilmişken (II: 405) Tunahan'a nispet edilen eserde "Mertebe-i Hullet” başlığı ile verilmiştir (s. 51). Tunahan'ın Mektuplar'ının elimizdeki asıl nüshasında ise yalnızca "Matlab" yazılıdır.

Oğuz'un 116 numaralı “Üç İctimâ' Tarîkat-i Sıddîkiyye’de Sülûk ve Vusûl Yolu” başlıklı mektubu (II: 396) Tunahan'a nispet edilen Mektuplar'da "Akreb-i Turuk-i Vusûl: Sohbet” şeklindedir (s. 54). Tunahan'ın asıl nüshasında ise başlık bulunmamaktadır. $^{9}$

Oğuz'un kitabında “İtmi’nân-1 Kalb” başliğıyla kayıtlı 155. mektup (II: 470) Tunahan'a nispet edilen Mektuplar'da “İtmi’nân-1 Kalbî Talebi” başlığı ile kayıtlıdır (s. 56). Her iki eserin asıl nüshalarında ise herhangi bir başlık bulunmamaktadır.

Oğuz'un Mektuplar'inda “İttihâm ve Muhâlefet-i Nefs” başlığı ile verilen 129 numaralı mektup (II: 419) Tunahan'a nispet edilen eserde "Nefs-i Emmâre ve İttihâm-1 Nefsî” başlı̆̆ ile yer almaktadır (s. 67).

Oğuz'un 57 numaralı “Mi’râc-1 Muhammedî” (I: 473) başlı̆̆ını taşıyan mektubu Tunahan'ın Mektuplar'ında "İsrâ" başlı̆ğ ile kayitlıdır (s. 92). ${ }^{10}$

9 Mektubun ikinci paragrafının sonunda yer alan "Bu husûsât, tarz-1 diğerde bizim 'Kitabü Âdâbi lMürîd'îmizde mezkurdur" ifadesi, Tunahan'ın Mektuplar'ina asıl teşkil eden el yazması nüshada “Kitabü Âdâbi>l-Mürîdîn 'imizde mezkûrdur” şeklinde yer almaktadır. Oğuz'un oğlu Abdulhalik Oğuz, torunu Mehmet İhsan Oğuz ve mektupları baskıya hazırlayan ve sadeleştiren Mustafa Bayburtlu ile görüşmemizde onlar Oğuz'un kitabının isminin "Kitâbü Âdâbi>l-Mürîd" değil, "Kitâbü Âdâbi lMürîdîn" olduğunu ve baskıya hazırlanan eserler arasında olduğunu ifade etmişlerdir. Ayrıca elimizde eserin Mustafa Bayburtlu'dan temin ettiğimiz 1971 tarihli yayımlanmamış ve muhtemelen daha sonra Oğuz tarafından sadeleştirilmiş bir nüshası mevcuttur. Kitabın isminin Tunahan'ın Mektuplar'ını baskıya hazırlayan kişilerce yanlışlıkla "Âdâbǜl-Mürîd" şeklinde kaydedildiği anlaşılmaktadır. Oğuz'un basıma hazırlanan eserleri arasında bu isimde bir kitabının bulunduğu ifade edilmesine rağmen Tunahan'ın söz konusu ismi taşıyan bir kitabı olduğu bilgisine hiçbir kaynaktan ulaşılamamıştır. Yaptığımız karşılaştırmadan anlaşıldığına göre Tunahan'ın Mektuplar'ında “Âdâb-1 Zarûriyye” başlığı taşıyan bölümün içeriğinin lafizları aynı olmasa da Oğuz'un "Kitâbü Âdâb-i>l-Mürîdîn” isimli eserinin içeriği ile uyuştuğu tespit edilmiştir.

$10 \mathrm{Bu}$ mektup hakkında 23 numaralı dipnotta bilgi verilmiştir.

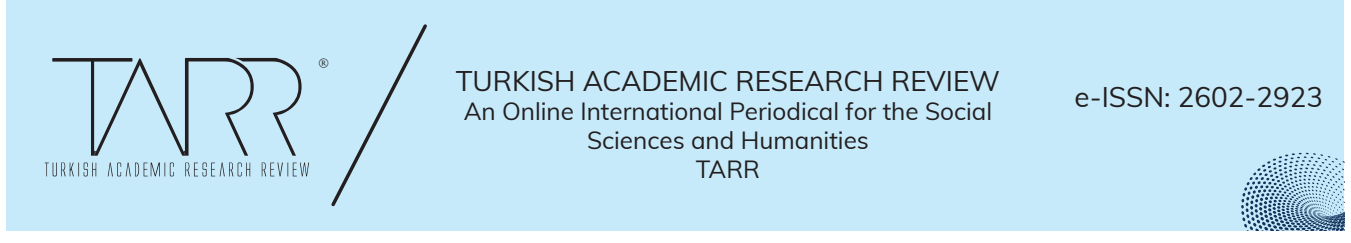


Oğuzun kitabında "Her gününü Bayram Edenler” başlığı ile verilen 4 numaralı mektup (I: 351) Tunahan'a nispet edilen Mektuplar'da “Her gününü Bayram Eden ve Her günü Hicranda Olan Velîler” başlığı ile verilmiştir (s. 96).

Oğuz'un kitabında "Sıhhatin Ehemmiyeti” başlı̆ğ ile kayıtlı 179 numaralı mektup (II: 512) Tunahan'ın kitabında "Sıhhat ve Sihhata I'tinâ Vazifesi” başlığı ile kayitlidır (s. 124).

Oğuz'un kitabında "Kardeşlerin Teksîri” başlığı ile verilen 73 numaralı mektup (I: 507) Tunahan'in Mektuplar'inda "Dinde Hakîki Kardeşlerinizi Teksîr Ediniz” başlığ ile yer almaktadır (s. 125). Bu mektubun ilk cümlesi Oğuz'da "Temenni, 'Dinde hakîkî kardeşleri teksir ediniz' haberine müsteniddir” şeklindedir. Tunahan'da ise "Temennî ...haberine müsteniddir" kısmı yer almadan "Dinde hakîkî kardeşleri teksir ediniz" şeklindedir.

Oğuz'un kitabında "Sâlihîn Sıfat-1 Celîlesi” başlıklı 38 numaralı mektup (I: 448) Tunahan'ın kitabında "Sâlihîn Tabirinin İsti'mâli” başlığı ile kayıtlıdır (s. 129).

Oğuz'un Mektuplar'ında "Sâdâtımızın Rüyaya Ehemmiyet vermedikleri” başlı̆̆ı (I: 461) Tunahan'in Mektuplar'inda "Rüya Bahsi” şeklindedir (s. 130).

Oğuz’un kitabında "Hatm-i Hâcegân” (II: 497) başlığını taşıyan bölüm Tunahan'ın kitabında "Hatm-i Hâcegân Âdâbı" üst başlı̆ğ ve "Hatm-i Hâcegânın Vaz'-1 Hakîkîsi ve Mâhiyeti” alt başlığı ile yer almaktadır (s. 163).

Oğuz'un kitabında yer alan 4 numaralı "Her Gününü Bayram Edenler" başlıklı mektubun (I: 352) bir kısm1, Tunahan'a nispet edilen kitapta "Kadir Gecesi" başlığı ile verilmiştir (s. 98). Yani mektup her ikisinde de bulunmaktadır, fakat farklı başlıklarla. Bu mektubun aslında önceki mektubun devamı olduğu ve Tunahan'ın kitabında bölümlenerek verildiği anlaşılmaktadır. Zira Oğuz’un kitabında paragraf "Gelelim Kadir gecesine: Bu geceyi idrak de ancak..." (I: 352) ifadeleri ile başlamaktadır. Tunahan'a nispet edilen eserin asıl nüshasında ise "Bu geceyi idrak de ancak..." şeklinde iken "de" bağlacı baskıya alınmamıştır (s. 98).

"Âdâb-1 Zikir” başlıklı mektup Oğuz'un kitabında da (II: 516) Tunahan'ın Mektuplar'ında da (s. 168) aynı başlık ile bulunmasına rağmen ikincisinde bazı alt başliklar ilave edilmiştir.

Oğuz'un kitabındaki 126 numaralı mektup “Aşk ve Mahabbet” başlığını taşırken (II: 417) Tunahan'ın kitabında "Mahabbet-i Aşk ve Heyemân” başlığına sahiptir (s. 42). Oğuz'un Mektuplar'ındaki "Lillâh ve fillâh mahabbetten neş'et eden hâlâtın semerât-1 sermediyye vermesi muhakkaktır” şeklindeki ilk cümle Tunahan'in Mektuplar'inda bulunmamaktadır.

Oğuz'un kitabında "Dâr-1 Cennette Rü’yet-i Hudâ, Kelime-i Tevhîd'in Merâtibi” başlığı ile verilen mektup (I: 394) Tunahan'a nispet edilen Mektuplar'da iki ayrı bölüm halinde "Tevhîd ve Derecât-1 Tevhîd" (s. 83) ve "Dâr-1 Cennette Rü'yet-i Hudâ” (s. 101) şeklinde verilmiştir. Bu mektubun Tunahan'in kitabında yer alan son paragrafı (s. 102) Oğuz’un kitabında yer almamaktadır.

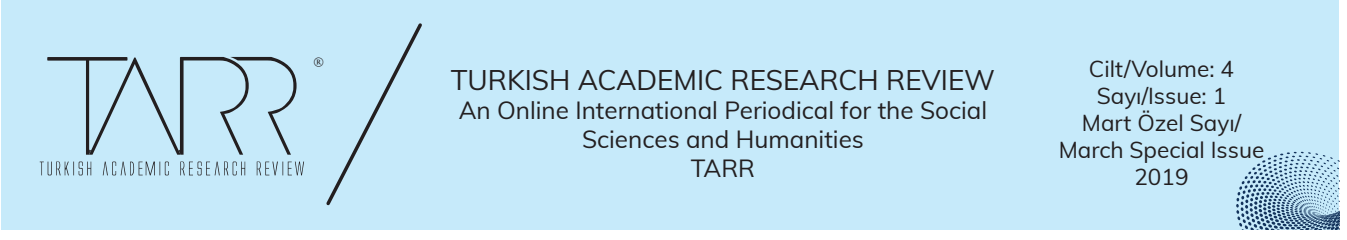




\subsection{Birinde Bulunduğu Halde Diğerinde Bulunmayan Mektuplar}

Tunahan'a nispet edilen kitapta bulunan bazı mektuplar, Oğuz'a nispet edilen kitapta yer almamaktadır. Örneğin; Tunahan'ın kitabında "Tarîk-i Vusûl-i Mahabbet” (s. 58), "İstirşâd Şerâiti” (s. 60), "Rabita Hakkında” (s. 65), "İrtibât-1 Mâddî - Fenâlar ve Nisyân-1 Mâsivâ" (s. 69), 11 "Terk-i Dünya” (s. 71), "Maddi Vücudun Âidiyeti” (s. 76), "Bir Mektuptan... Fenâ-yı Hakîkî" (s. 81), ${ }^{12}$ başlıklarını taşıyan mektuplar tespit edebildiğimiz kadarı ile Oğuz'un kitabında bulunmamaktadır.

Tunahan'ın Mektuplar'ında “Âdâb-1 Zarûriyye” (s. 146) başlığını taşıyan bölüm de Oğuz'un Mektuplar'ında bulunmamaktadır. Yaptığımız inceleme neticesinde söz konusu kısmın, Oğuz'a ait bir başka eser olan Kitâbü Âdâbi'l-Mürîdîn'in içeriği ile örtüştüğü tespit edilmiştir. Ancak Oğuz'un Âdâbü'l-Mürîdîn'inin elimizdeki nüshası sadeleştirilmiş bir nüsha olduğu için ${ }^{13}$ bu örtüşme, birebir ifadelerin örtüşmesi şeklinde değil, mazmûn ve muhtevanın aynı olması şeklindedir. Oğuz'un Kitâbü Âdâbi'l-Mürîdîn isimli eseri, kendisinin de baş kısminda belirttiği gibi İmâm Rabbâni'nin (ö. 1034/1624) bir mektubu ${ }^{14}$ ile onun oğlu Muhammed Masum'un (ö. 1079/1668) bir mektubundan, metinde bazı düzeltmeler (tankîh) ve düzenlemeler (tanzim) yapılarak asıllarının aynen nakledilmesi ile meydana getirilmiş tercüme bir eserdir. ${ }^{15}$ Âdâbül-Mürîdîn'in bizim ulaşabildiğimiz nüshası 1971 tarihli, latin harfleri ile daktiloda yazılmış ve henüz yayımlanmamış halidir. Ancak Oğuz'un zaman zaman müntesiplerine göndermek için eserlerini istinsah ettiği ve bu esnada gördüğü lüzum üzerine farklı ifadeler kullandığı, ekleme, çıkarma ve bazı düzenlemeler yaptığı bilinmektedir. Tunahan'a nispet edilen eserde "Âdâb-1 Zarûriyye” başlığ 1 taşıyan bölümde görülen ifade değişiklikleri, takdim-tehir, ilave-noksanlıklar gibi farklılıkların sebebi bu olmalıdır. Başka bir deyişle bu eserin elimizdeki 1971 tarihli nüshadan daha önce Oğuz tarafından yazılmış ve müntesiplerinden birine gönderilmiş başka bir nüshaya ${ }^{16}$ dayandığını söylememiz mümkündür. Burada Âdâbü'l-Mürîdîn isimli eserin aslında Tunahan'a ait olabilece-

11 Tunahan'a nispet edilen Mektuplar'da yer alan bu mektup, her ne kadar Oğuz'un Mektuplar'inda yer almasa da bunun da Oğuz'un mektuplarından biri olduğu anlaşılmaktadır. Mustafa Bayburtlu'nun bu mektup hakkındaki ifadesi: "İrtibât-1 Maddî - Fenâlar ve Nisyân-1 Mâsivâ" başlıklı ve son parağrafında “Benim sizi terk etmeme acabâ imkân mutasavver midir?" cümlesinin yer aldığı mektup, basılı mektuplardan olmayıp Hayri Bey tarafından istinsâh edilmiş nüshası bende bulunmaktadır. Fotoğrafını size göndermiştim. Bunun, Mektuplar basıldıktan sonra elime geçtiğini ve o sebeple esere konulamadığını zannediyorum."

12 Bu mektup hakkında Bayburtlu'nun tarafımıza gönderdiği yazılı not: "81 sahife numaralı ve "Fenâ-y1 Hakîkî” başlıklı ("Onlar bizi unutuyor zannetmesinler...” cümlesiyle başlayan) mektubun da Beyefendi'ye [M. İhsan Oğuz] âid olduğunu biliyor, daha önce okuduğumu hatırlıyorum. Fakat, aramama rağmen bir nüshasını bulamadım."

13 Oğuz'un Mektuplar'ını baskıya hazırlayan Mustafa Bayburtlu'nun bu nüsha ile ilgili yazılı olarak tarafımıza gönderdiği not şu şekildedir: "Bu nüsha, herhangi bir kimse tarafından sadeleştirilmiş değildir. Belki kendileri [Oğuz], okuyanların daha rahat anlamaları için 1971 tarihli bu nüshayı biraz daha sade yazmış olabilirler. Kütükte yer alan ve çok önce yazılmış bulunan diğer Âdâbü'l-Mürîdîn nüshası, bundan biraz farklı olsa gerektir. Zîrâ; önceki nüshada yer aldığını hatırladığım "Tâliblerin Âdâb-1 Zarûriyyeleri” ara başlı̆̆ı, 1971 tarihli nüshada yoktur."

14 Bu mektup, İmâm Rabbânî’nin Hamîd el-Bingâlî’ye yazdığı 292 numaralı mektuptur. İmâm Rabbânî, Ebü'l-Berekât Ahmed b. Abdilehad b. Zeynilâbidîn el-Fârûkî es-Sirhindî, Mektûbât, İstanbul: İhlâs Vakfi, 1423/2002, I: 586.

15 Oğuz, Kitâbü Âdâbi'l-Mürîdîn, 2-3.

16 Bir müellifin, kitabını ilk nüshadan sonra tekrar kaleme almasına "ibrâze" denir ki bu, günümüzde kitapların tekrar baskılarına karşılık gelmektedir. Mustafa Şevkî Binbîn-Mustafa Tûbâ, Mu'cemü Mustalâhâti'l-Mahtûti'l-Arabî, 3. bs., Merakeş: el-Hizânetü 'l-Haseniyyeti'r-Ribât, 2005, 29.

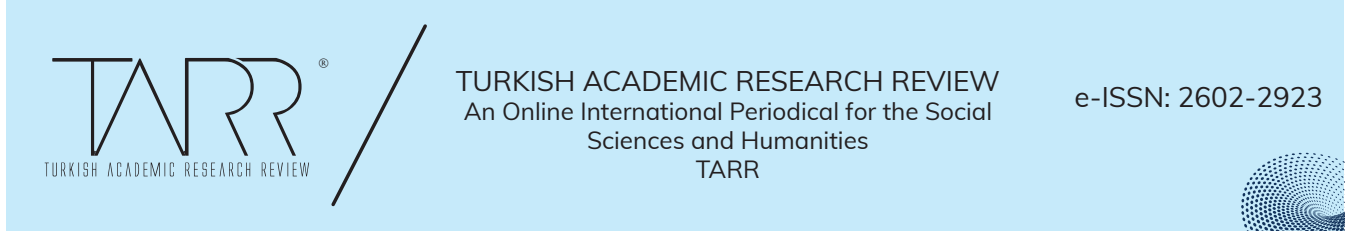


ği gibi bir itiraz yöneltilebilir. Ancak bugüne kadar talebeleri dahil hiç kimseden onun bu isimde bir eser yazdığına dair bir nakil duyulmamıştır. Öte yandan elimizde bu eserin Muhammed İhsan Oğuz'a ait olduğunu gösteren 1971 tarihli bir nüshası mevcuttur. Ayrıca oğlu, torunu ve diğer sevenleri tarafından söz konusu eserin Oğuz'a aidiyeti onun hayatta olduğu dönemden bu yana bilinmektedir. ${ }^{17}$

Tunahan'a nispet edilen Mektuplar'da bulunduğu halde Oğuz'a nispet edilen Mektuplar'da bulunmayan başka bazı mektuplar da bulunmaktadır. Aksi durum ise çok daha fazla sayıda mektup için söz konusudur.

\section{Değerlendirme}

Oğuz'a nispet edilen Mektuplar ile Tunahan'a nispet edilen Mektuplar'in mukayesesinden anlaşıldığına göre her iki eserde de mektupların büyük kısmı birebir aynı ifadelerle yer almaktadır. Bazı mektupların özellikle baş ve son kısımlarında kimi ifadeler birinde bulunduğu halde diğerinde bulunmamaktadır. Bunun dışında mektupların başlıklarında da bazı farklılıklar göze çarpmaktadır. Başlıklardaki farklılıklar, Mektuplar'ı gönderildikleri kişilerdeki asıllarından istinsah eden ya da baskıya hazırlayan kişilerden kaynaklanmaktadır. Oğuz'un kitabında yer alan başlıkların büyük kısmı, mektupları asıllarından istinsah eden Hayri Taptık tarafından muhtevaları göz önünde bulundurularak konulmuş ve baskıya da buradan alınmıştır. Bazı başlıklar ise Mektuplar'ı baskıya hazırlayan Mustafa Bayburtlu tarafından konulmuştur. Tunahan'a nispet edilen baskıdaki başlıkların bir kısmı el yazması asıl nüshada mevcut olup, bazıları ise asıl nüshada yoktur. Asıl nüshada bulunanların, mektupların kendisinden ilk intikal ettiği kişi tarafından konulduğu anlaşılmaktadır. Diğerleri ise eserleri baskıya hazırlayan kişiler tarafından konulmuş gözükmektedir.

Yukarıda bir kısmını göstermeye çalıştığımız bazı farklılıklar dışında her iki eserde yer alan metinler aynıdır. Tunahan'in kitabında yer alan az sayıda mektup Oğuz'un kitabında, Oğuz'un kitabında bulunan çok sayıda mektup ise Tunahan'ın kitabında yer almamaktadır. Yani Oğuz'un kitabı Tunahan'ın kitaplarındaki mektupların çoğunluğunu ihtiva ederken Tunahan'ın kitabı ise Oğuz'un kitabındaki mektupların az bir kısmını ihtiva etmektedir. Oğuz'a nispet edilen eserde bulunmayan mektupların onun henüz basılmayan eldeki mektupları arasında bulunması ya da ulaşılamayan mektuplarından bazıları olması muhtemeldir.

Tunahan'a nispet edilen, ancak üzerinde müellif ismi bulunmayan Kibrît-i Ahmer isimli risâle, Oğuz'un Mektuplar'inda "Muâmelât-1 Zâtiyye ve Sifâtiyye, Avâlim-i Mâddiyye ve Ma'neviyye” başlığı ile mevcuttur (I: 368-385).

Tunahan'a nispet edilen Kibrît-i Ahmer'in devamında basılan İksîr-i Ulûm ve Ma'rifet isimli risâle, Oğuz'un Mektuplar'inda yer almamaktadır. Oğuz'un varisleri onun yayıma hazırlanmakta olan eserleri arasında bu isimde bir kitabının bulunduğunu ifade etmişlerdir.

17 Oğuz'un Kitâbü Âdâbi'l-Mürîdîn isimli eserinin Hayri Taptık'ın istinsah ettiği kütükte kayıtlı nüshasının daha uzun olduğu Mustafa Bayburtlu tarafından ifade edilmiştir. Dolayısıyla kütükteki nüsha, Tunahan'ın eserindeki "Âdâb-1 Zarûriyye" başlığı taşıyan bölüm ile aynı ifadelere sahip olabilir. Ancak şimdilik bunu kütükten tashih etme imkânımız olmamıştır.

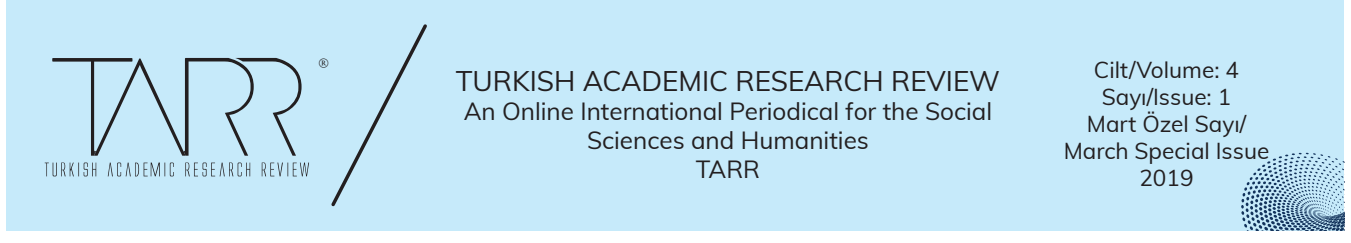




\section{Mektuplar Kimlere Yazılmıştır?}

Oğuz’un mektuplarının büyük kısmı, ihvânından Hayri Taptık (ö. 1968), ${ }^{18}$ Rahmi Köseoğlu (ö. 1972), ${ }^{19}$ Vehbi Bilimer (ö. 1970), ${ }^{20}$ Hilmi Turgay (ö. 1968),

18 Hayri Taptık Arapça ve Farsça bilen, ilim sahibi, PTT müfettişliği yapmış bir zattır. Muhammed İhsan Oğuz ile Kastamonu'ya gittiği bir teftiş esnasında tanışmışlardır. İstanbul Büyükşehir Belediyesi Atatürk Kitaplığı Osman Ergin yazmaları O.E.1813 numaralı Vahdet-i Vücûd ve Vahdet-i Şühûd Münakaşaları isimli yazma eserde yer alan 17 Mart 1920 tarihli Oğuz'a ait 3 numaralı mektubun baş kısmındaki "Hayri Bey Efendi'ye takdim etiğim bazı âsârın mütalaasından hâsıl ettikleri intıbââtı mutazammın yazılarınızı minnetle ahz ve mütâlaa eyledim" (s. 15) yazısından hareketle Hayri Taptık'ın Oğuz ile tanışıklığının bu tarihten (17 Mart 1920) önce olduğunu söylememiz mümkündür. Oğuz'un ihvanından Rahmi Köseoğlu, Hayri Taptık, Konya Lezzet Lokantası sahibi Mustafa Doğanbey, Hüsnü Bayer, Seniyyüddin Başak ve o zamanlar bağlısı olan Vehbi Bilimer gibi isimler aynı zamanda İlim Yayma Cemiyeti kurucularındandırlar. Oğuz'un bunlar dışında İlim Yayma Cemiyeti kurucularından Rahmi Köseoğlu'nun kardeşi Ahmet Ata Köseoğlu, Refik Bürüngüz (https://iyc.org.tr/kurucularimiz, erişim: 11.01.2019) ve başka bazı isimler ile de yakın münasebetleri olduğu bilinmektedir.

Oğuz'un kitabındaki 35 numaralı mektup (I: 435) Süleyman Hilmi Tunahan'a nispet edilen Mektuplar'da “Temessük-i Hakîkî” başlığı ile (s. 22) ile kayıtlıdır. Bu mektubun kime yazıldığı ile ilgili Mustafa Bayburtlu'nun tarafımıza yazılı olarak gönderdiği not şu şekildedir:

“35 numaralı mektubun Hayri Bey’e [Hayri Taptık] yazıldığı bellidir. Hem mektubun mâhiyyeti ve başında yer alan ifâde, hem de Tunahan'a nisbet edilen nüshadaki “1923” [23 Şaban 1341/10 Nisan 1923] tarihi, bunu göstermektedir. Hayri Bey cezbeli bir zât olup Vahdet-i Vücûd'a temâyülü, İstanbul'da birçok kimse ile temâsı varmış. Her birini hakîkat ehli zannettiği için onlardan aldığı bâzı yanlış düşünceleri atabilmesi kolay olmamış, Beyefendi [Oğuz], nisbet talebini bu sebeple uzun müddet (üç seneyi aşkın bir süre) askıya aldıktan sonra (kendisinin bundan üzüntü duyması üzerine) kabûl etmiş. Bu konuyu, eniştem Sâcid Ağabey'le [Sâcid Çubukçu] birlikte Rahmi Beyamca'dan [Rahmi Köseoğlu] dinlemiştik. Bu süre zarfında Beyefendi, Hayri Bey'in hüsn-i zan beslediği ve kendisini tanıştırmak istediği çeşitli kimselerle, O’nun arzusu üzerine görüşmüş. Bunlardan bâzılarıyla ilgili hâtıraları Beyefendi'den de dinlemiştik. İşte (35 numaral1) mektubun girişinde dile getirdikleri "mükteseb hukuk", gerek Posta ve Telgraf İdâresi'nde geçen resmî münâsebet, gerekse o vesîle ile teessüs eden dostluk ve arkadaşlık hukukudur. İntisâb ile başlayan yeni ve farklı bir münâsebetten dolayı o hukukun unutulmayacağını ifâde etmek istemişlerdir. Rahmi Bey'e yazılan mektup gibi bu mektup da, yolun esaslarını bildiren, aynı zamanda Hayri Bey'in hâlini de nazar-1 îtibâra alan bir irşâd mektubudur. Bu yolda düşülebilecek hatâları ifâde ederken Vahdet-i Vücûd'dan da bahsetmeleri, bunun bir göstergesidir."

Oğuz'un kitabındaki 116 numaralı mektup ile ilgili Bayburtlu'nun tarafımıza gönderdiği not da şu şekildedir: "116 numaralı mektubun muhâtabı da Hayri Bey'dir. Bu mektubun kütüğe geçirilen nüshasında “üç misâlî ictimâ”” yoktur. Hayri Beyamca, kendisiyle ilgili bir durum olduğu için (başka mektuplarda olduğu gibi) bunu da kütüğe yazmamıs. Ben bu mektubun orijinalini, Sâcid Ağabey'in Âkif Beyamca'dan [Âkif Kuyulu] emâneten aldığı mektuplar arasında gördüm. Âkif Beyamca bunları imhâ etmek istediğini söylemiş; Sâcid Ağabey de, okumak üzere bir müddet kendisinde kalması için izin alıp getirmişti. Birlikte okumuştuk. Âkif Beyamca'ya da, herhalde (Hayri Bey'in yakın arkadaşı olan) ağabeyi Dr. Hakkı Rüşdü Bey'den geçmiştir. Hayri Bey'e yazılan mektubun başındaki bu üç ictimâ1 görünce, (okuyanların ders çıkaracağı hususlar olduğu için) istinsâh ederek basılacak mektuba onu da koydum.”

19 Rahmi Köseoğlu Sirkeci'de bir iş hanında Vehbi Bilimer'in iş ortağıdır. Onun Muhammed İhsan Oğuz ile tanışmasına Hayri Taptık vesile olmuştur. Nitekim bu durum, Oğuz'un Mektuplar'ında onun Rahmi Bey'in intisap talebine verdiği cevapta "Hayri Bey tarafından şahsınız hakkında vâki' iş'ârâtı da nazar-1 itibâra alarak" şeklinde ifade edilmiştir (I: 337). Hayri Taptık kendi isminin geçtiği yeri kütükte (...) şeklinde noktalar koyarak vermiştir. Mustafa Bayburtlu mektubun kendisine yazıldığı Rahmi Köseoğlu'ndan buradaki ismin "Hayri Bey” olduğunu öğrenerek ismi baskıya almıştır. Tunahan'ın Mektuplar'ında ise ilgili bölüm "Hayri Bey tarafından" ifadesine yer verilmeksizin "Şahsınız hakkında vâki' iş’ârâtı da nazar-1 itibâra alarak" şeklindedir (s. 9). Tunahan'ın Mektuplar'ında "Rahmi Bey'e Yazılan Mektubun Bazı Kısımları" (s. 119) ifadesi ile kastedilen kişi Rahmi Köseoğlu olmalıdır.

Oğuz'un Mektuplar'ında "Rahat Hayat” başlığı ile kayıtlı 199 numaralı mektup (II: 559) 15.08.1967 tarihinde Oğuz tarafından Rahmi Köseoğlu’na yazılmıştır. Bu mektubun Bayburtlu'dan temin ettiğimiz orijinal nüsha fotokopisinin bir sureti tarafımızda mevcuttur.

20 Vehbi Bilimer, İlim Yayma Cemiyeti kurucularından ve 1961-1968 yılları arasında cemiyetin başkanlığını yapmış bir zattır.

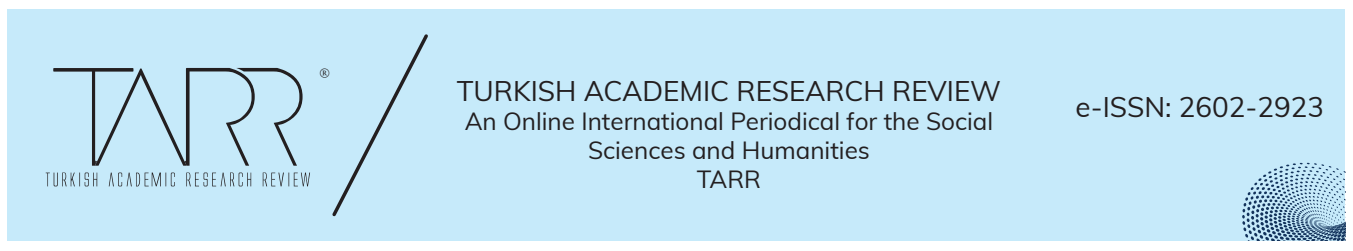


Dr. Hakkı Rüştü Kuyulu (ö. 1973), ${ }^{21}$ Mustafa Atak (ö. 1973), ${ }^{22}$ eski Çorum Mecitözü ilçesi Müftüsü Yahya Akbaş (ö. 1987), eski Tokat Zile Müftüsü Ârif K1lıç (ö. 1972), eski Amasya Müftüsü (Ârif Kılıç'ın Amasya Medresesi'nden hocası olan) Sabri Yetkin (ö. 1962), Oğuz’un dâmâdı Mehmet Âkif Kuyulu (ö. 1997), Mustafa Ulak, eski Çorum Müftüsü Mustafa Özel, Seyyid Ahmed el-Kürdînnin (ö. 1921) ihvânından Harput Ulu Câmii İmamı Hacı Tevfik Efendi (ö. 1951) gibi muhtelif kişilere yazılmıştır. Oğuz'un bu kişiler dışında Ahmed Avni Konuk (ö. 1938), İzmirli İsmail Hakkı (ö. 1946), Ali Fuat Başgil (ö. 1967) gibi çok sayıda ilim adamı ile de müteaddit mektuplaşması mevcuttur. ${ }^{23}$ Bu mektupların bir kısmının sahiplerinde kalmış olması, bir kısmının dönemin siyasi baskıları sebebiyle

21 Mustafa Bayburtlu'nun Hakkı Rüştü Kuyulu'ya yazılan bir mektup ile ilgili ifadesi: "54 numaralı (“Muhterem Hakkı Beyefendi!” diye başlayan) mektup, Dr. Hakkı Rüşdü Kuyulu’ya yazılmıştır. Hayri Beyamca bu mektubu kütüğe geçerken baş tarafını ve ikinci sahifesini (Hakkı Rüşdü Bey'in şahsına müteallık olduğu için) almamış. Ben mektubun aslını, 1. cild basıldıktan sonra gördüm. Önceden görse idim, (ders alınacak önemli bilgilerin bulunduğu) ikinci sahifeyi de, (116 numaralı mektuptaki Üç İctimâ'da olduğu gibi) basılan nüshaya koyardım.”

22 Mustafa Bayburtlu'nun bildirdiğine göre Oğuz'un 118 numaralı "Hakîkat-i Muhammediyye” başlığını taşıyan mektubu bu zata yazılmıştır (II: 402).

23 Oğuz'un Avni Konuk ile yaptığı Vahdet-i Vücûd ve Vahdet-i Şühûd tartışmaları hakkında Bayram Kusursuz tarafından 2003 yılında Marmara Üniversitesi Sosyal Bilimler Enstitüsü'nde "Ahmet Avni Konuk’un Vahdet-i Vücûd Müdâfaası" başlıklı bir yüksek lisans tezi hazırlanmıştır.

Araştırmamız sırasında İhsan Oğuz'un Mir'ât-ı İmâm-ı Rabbânî isimli eserinin İstanbul Büyükşehir Belediyesi Atatürk kitaplığında Osman Nuri Ergin tarafından müellif nüshasından 1 Şubat 1932'de istinsah edilmiş bir başka nüshasına da ulaştık (İstanbul Büyükşehir Belediyesi Atatürk Kitaplığı Demirbaş no: O.E.1174, 112). Bu kitap Oğuz'un, Abdülmecîd b. Muhammed Hânînin (ö. 1318/1900) el-Hadâiku'l-Verdiyye fì hakâ'iki ecillâ'i'n-Nakşibendiyye'sinden (bkz. Osman Türer, "Hânî, Abdülmecîd b. Muhammed”, Türkiye Diyanet Vakfi İslâm Ansiklopedisi, (İstanbul: TDV Yay., 1997), 16: 29-30) istifade ile hazırladığı bir eserdir. Söz konusu Mir'ât isimli eserin araştırmamız açısından önemi yine Süleyman Hilmi Tunahan'a nispet edilen Kibrît-i Ahmer ismiyle basılmış risâlede bu esere "Vasl-i uryân Kitâb-ı Mir'ât'da yazılıdır” (Kibritt-i Ahmer, 19) ifadeleri ile atıf yapılmıs olmasıdır. Tunahan'ın Mir'ât isminde bir kitabı bilinmezken Oğuz'un bu isimde, üstelik "vasl-i uryân”dan bahseden bir eseri mevcuttur (bkz. Oğuz, M. İhsan, Mir'âtı-ı İmâm-ı Rabbânî, İstanbul Büyükşehir Belediyesi Atatürk Kitaplığı, Müstensih: Osman Ergin, İstinsâh Tarihi, 1 Şubat 1932, No: O.E.1174, 97-100). Bu durum, Kibritt-i Ahmer ismiyle basılan risâlenin Muhammed İhsan Oğuz'a aidiyetini ispatlamaktadır. Ayrıca bu risâle, Oğuz'un Mektuplar'ında "Muâmelât-1 Zâtiyye ve Sıfâtiyye, Avâlim-i Maddiyye ve Ma'neviyye" başlığı ile basılmıştır (I: 368). Bunun dışında Osman Nuri Ergin yazmaları arasında “İhsan Beyin İzmirli İsmail Hakkı Bey’e Bir Mektubu” başlığını taşıyan bir nüshaya ulaştık. Bu nüshanın Mektuplar'ın içerisinde yer alan (Mi’râc-1 Muhammedî” başlıklı 57. mektubun (I: 473-477) Osman Nuri Ergin tarafından kaleme alınan bir nüshası olduğu tespit edilmiştir. Kütükte bir kayıt bulunmadığı için kime yazıldığı bilinmeyen mektubun bu nüshasının üzerine, müstensih tarafından “İhsan Bey’in İzmirli İsmail Hakkı Bey’e Bir Mektubu” başlı̆̆ düşülmüsstür. 20 Kânûn-1 Evvel 1932 tarihli bu nüshadan, söz konusu mektubun Oğuz tarafından İzmirli İsmail Hakkı’ya yazıldığını tespit etmiş bulunuyoruz (İstanbul Büyükşehir Belediyesi Atatürk Kitaplığı Demirbaş no: O.E.824, 60-65). Bu mektubun üzerinde bulunan istinsah tarihi, araştırmamız için son derece önem arz etmektedir. Zira aynı mektup, Tunahan'a nispet edilen eserde de "İsrâ" başlı̆̆ ile yer almaktadır (s. 9296). Buna göre bu belge çok eski bir tarihte yani 1932 yılında bu mektubun Muhammed İhsan Oğuz’a aidiyetini ortaya koymaktadır. Mektuplarla ilgili ulaşabildiğimiz en eski tarihli belge budur. Ayrıca bu tarih, her iki eserde de birinci sırada basılan mektubun yazım tarihi ile ilgili olarak Rahmi Köseoğlu'na yazılan mektubun, Bayburtlu'nun kendisinde bulunan bir istinsahının üzerinde bulunan 10 Muharrem 1351 yani 16 Mayıs 1932 tarihi ile de uyuşan bir tarihtir.

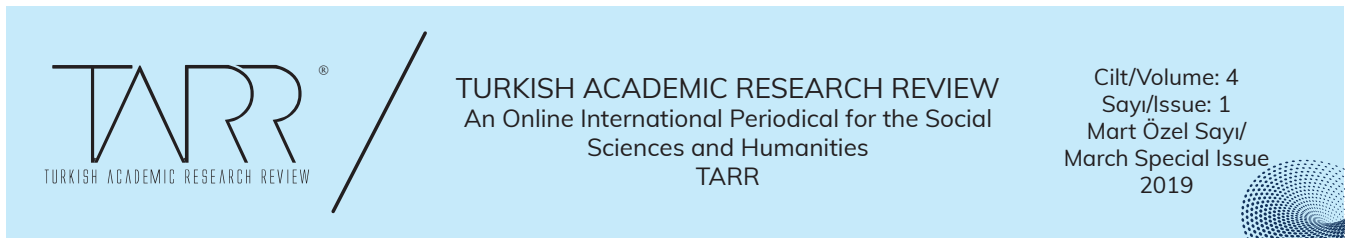


bizzat kendisi tarafından imhasının istenmiş olması, ${ }^{24}$ her bir mektubun yazıldığ kişilerin kesin olarak bilinmesi imkânını oldukça zorlaştırmaktadır. ${ }^{25}$

Oğuz'un Mektuplar'ının büyük kısmı, onun bağlılarından Hayri Taptık'ın, gönderildiği kişilerden izin alarak mektupları kaydettiği "kütük" tabir edilen ve üç ciltten oluşan defterlere dayanmaktadır. ${ }^{26}$ Hayri Taptık, Oğuz'un bağlılarına gönderdiği mektupları baştaki özel kısımları çıkararak Osmanlı Türkçesi ile kaydeder ve bugün elimizdeki Mektuplar bu şekilde bir araya getirilir. Hayri Taptık söz konusu defterleri, içindeki bilgilerin zayi olmasını istemediği için "Bizim çocuklar bunların kıymetini bilmez, bunların kıymetini ancak sen bilirsin!” diyerek vefat etmeden önce Rahmi Köseoğlu'na ${ }^{27}$ emanet eder. $\mathrm{O}$ da aynı gerekçe ile vefat etmeden önce Sâcid Çubukçu'ya (ö. 2015) ${ }^{28}$ teslim eder. Mektupların kaydedildiği defterler (kütükler) Oğuz adına Kastamonu'da kurulan vakıf bünyesinde şu an varislerinin elindedir. Basılmış eserin ikinci cildinin son kısmında yer alan mektupların bir kısmını, söz konusu kütükte olmayan mektuplar oluşturur. Oğuz'un damadı Akif Kuyulu'dan temin edilen bu mektuplar, Mustafa Bayburtlu tarafindan yayım esnasında ikinci cildin sonuna eklenir. ${ }^{29}$ Bayburtlu'nun ve Oğuz'un varislerinin bildirdiğine göre Hayri Taptık bazı mektupların karşısına yazıldığı kişiyi bildiren bir rumuz koyar. Örneğin Rahmi Köseoğlu'na yazılan mektup için (ر) harfini yazar. Basılı eserde yer alan 1 numaralı mektup Rahmi Köseoğlu’nun Sâcid Çubukçu'nun evini ziyaret ettiği bir gün kendisine "Hayri Bey’in kütüğe yazdığ 1 önemli bir mektup var, size de okuyalım” denilerek okununca Rahmi Köseoğlu gülümseyerek "Bu mektup bana yazılmıştı" der. Böylece kütükteki bazı mektupların karşısında yer alan rumuzların manası anlaşılmış olur. Oğuz'un iki cilt olarak basılan Mektuplar dışında henüz yayımlanmamış mektupları da mevcuttur. Diğer

24 Örneğin; Mustafa Bayburtlu'nun bildirdiğine göre 1948'de yazılmış olan 146 numaralı mektubun ikinci sayfasındaki (Mektuplar eserinde yer almayan) ekinde: "Vehbi Beyefendi'ye: Mektubun ortasındaki ilâvenize cevap vermiş oluyorum. Mektup sûretlerini okuduktan sonra imhâ edersiniz. Beş arkadaş okursunuz. Hamdi Bey de okusa iyi olur. Tahammülü olanlara da okutulabilir. Mehmed Ermiş gibi... Leyle-i Kadr mev'ıasını Atâ Bey ve herkes okusun, talebeler de..." denilmektedir. Bayburtlu'nun konu ile ilgili açıklaması şu şekildedir: "Mektubun "Rahmi, Hayri, Dr. Hakkı Rüşdü, Vehbi” Beyler'e yazıldığı anlaşılmaktadır. "Beş arkadaş okursunuz" denildiğine göre, bir kişi daha var. Onun da "Mustafa Doğanbey" olması mümkindir. Başkası da olabilir. Mektupta sözü edilen talebeler, (İlim Yayma Cemiyeti o tarihte henüz kurulmadığına göre) bu zevâtın ilgilendiği ve himâye ettiği talebeler olsa gerek."

25 Oğuz'un torunu Mehmet İhsan Oğuz'a, mektupların asıllarına ulaşma imkânı bulunup bulunmadı̆̆ını sorduğumuzda bu vesileyle onun mektup gönderdiği bilinen sevenlerinin bugün hayatta olan yakınlarında, ellerinde asıllarının bulunup bulunmadığını araştıracaklarını ifade etmişlerdir.

26 Söz konusu kütüklerin içerisinde Oğuz'un mektupları dışında diğer bazı eserleri de bulunmaktadır.

27 Tunahan'a nispet edilen Mektuplar'da "Rahmi Bey'e Yazılan Mektubun Bazı Kısımları" (s. 119) ifadeleri ile kastedilen kişi Oğuz'un ihvanından Rahmi Köseoğlu olmalıdır. Süleyman Hilmi Tunahan'ın "Rahmi Bey" isimli bir şahsa mektup yazdığı tarafımızca tespit edilememiştir. Rahmi Bey'in kim olduğu sorusuna cemâat mensubu hiçbir kimseden net bir cevap alınamamıştır. Tunahan'ın bağlılarından Ramo Amca isimli bir zat olabileceğine yönelik bir takım yorumlar duymuş olmamıza rağmen bu yorumu destekleyen herhangi bir delile ulaşılamamıştır. Üstelik bilindiğine göre Ramo Amca okuma yazma bilmemektedir. Okuma yazma bilmeyen birine mektup yazılması tutarlı olmadığı gibi Ramo Amca'nın Tunahan'ın kendisine mektup yazdığına dair bir beyanına da ulaşılamamıştır.

28 Sâcid Çubukçu, Mektuplar ile Oğuz'un başka birçok kitabını sadeleştiren ve yayına hazırlayan Mustafa Bayburtlu'nun eniştesi (halasının eşi)dir.

29 Mustafa Bayburtlu'nun ifade ettiğine göre basılan mektupların en az dörtte biri kütük dışındandır.




kitapları ile birlikte basılmamış mektupları da Oğuz Vakfı tarafından yayıma hazırlanmaktadır.

Tunahan'ın mektup yazdığı kişiler ise tarafımızdan tespit edilememiştir. Araştırmamız sırasında günümüzde hayatta bulunan talebelerinden hiçbirisinin, Tunahan'ın kendilerine bu mektuplardan yazdığına yönelik bir ifadesine ulaşılamadığ gibi vefat etmiş bulunan talebelerinden de bu yönde bir nakle ulaşılamamıştır. Tunahan'ın önde gelen talebelerinden ve bir müddet Çatalca müftülüğü de yapmış olan Lütfi Davran'a gönderdiği belirtilen kısa bir not dışında herhangi bir mektup yazdığı tarafımızca tespit edilememiştir. Söz konusu not ise Mektuplar'da yer almamaktadır. Bu konuda ulaşabildiğimiz başka bir açıklama Tunahan'ın talebelerinden Mustafa Arıkan'a aittir. Süleymanlı Cemaatinin çıkardığı Ufuk gazetesinin 13 Eylül 1978 tarihli sayısında Tunahan'ın talebelerinden Arıkan ile yapılan bir röportajda ondan Tunahan'ın el yazmalarından örnekler istendiği, onun;

"Bende Üstadımızın birçok mektubu var idi. Fakat o devirde hizmetlerimize gelecek zarara imkân vermemek için, baskıncıların, din düşmanlarının ellerinde vesika olmasın diye hepsini kaybettik, elden çıkardık, bugün bir tane mektubu bile maalesef yok."

cevabını verdiği yazılıdır. Arıkan'ın kastettiği mektuplar, elimizde bulunan Mektuplar ve Bazı Mesâil-i Mühimme adıyla basılmış eserde yer alan mektuplar olmalıdır. Zira bu eserin aslını teşkil eden elimizdeki el yazısı notların bir bölümünün baş kısmına sonradan eklendiği anlaşılan "Bu yazı babamın yazısı. Hasan Arıkan”30 notu düşülmüştür. Bir bölümün baş kısmında "Lütfi Davran'dan Gelen" notu, başka bir bölümde ise "Biletçi Mehmet Efendi" 31 yazısı mevcuttur. Ancak Mustafa Arıkan'ın yukarıdaki sözleri de mektupların kimlere yazıldığını açıklığa kavuşturmamaktadır. Eğer nüshanın üzerinde yer alan bu notlar doğru ise mektupların aslını teşkil eden el yazması nüshaların Mustafa Arıkan, Lütfi Davran ve Mehmet Akçelioğlu'ndan cemaate intikal ettiğini söylememiz mümkündür. Fakat bu notların doğru olmama ihtimali de vardır. Zira Arıkan'ın elde hiç mektup kalmadığını ifade etmesine rağmen Ufuk gazetesinin başka bir sayısında Tunahan'in bir başka talebesi Mehmet Aksoy'un (Ahbap Hoca, ö. 1978) ${ }^{32}$ teksir edip talebelerine dağıttığı ifade edilen bu mektupların yayımlanmaya başlanması izaha muhtaçtır. ${ }^{33} \mathrm{O}$ halde eldeki el yazması notların Mustafa Arıkan'dan ziyade Lütfi Davran, Mehmet Akçelioğlu ve Mehmet Aksoy'dan birinden ya da hepsinden intikal etmiş notlar olması gerekmektedir. ${ }^{34}$

30 Hasan Arıkan, Mustafa Arıkan'ın oğludur. Her ikisi de Süleyman Hilmi Tunahan'ın talebeleridirler.

31 Mehmet Akçelioğlu Süleyman Hilmi Tunahan'ın talebelerindendir.

32 Mehmet Aksoy, Süleyman Hilmi Tunahan'ın önde gelen talebelerindendir. Bir müddet Afyon'un Şuhut ilçesi müftülüğü görevinde bulunmuştur.

33 Bkz. Ufuk, (Haftalık Siyasî Gazete), 6 Eylül 1978, sayı: 474: 7.

34 Mustafa Arıkan'ın oğulları, aynı zamanda Tunahan'ın da talebeliğini yapmış olan Hasan Arıkan ve Mehmet Arıkan kardeşlerin konuya ilişkin bilgilerinin olması mümkündür. Ancak tüm gayretlerimize rağmen kendileri ile görüşme imkânı elde edilememiştir.

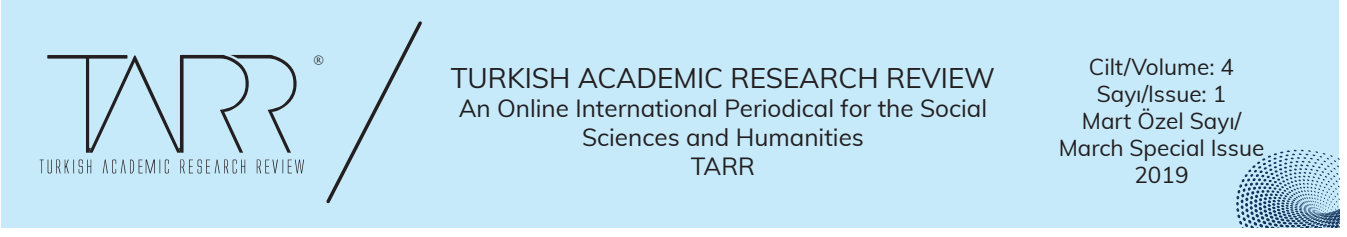


Bütün bunlar, mektupların Tunahan tarafından kimlere yazıldığını açıklığa kavuşturmasa da o tarihte henüz basılmamış olan metnin Tunahan'a aidiyetinin 1978 yılında cemaat içerisinde en azından belli bir kesim tarafından bilindiğini ve konuşulduğunu tartışmasız biçimde ortaya koymaktadır.

Diğer taraftan söz konusu metnin aslında gerçek kişilere yazılmış gerçek mektuplar olmadığı, bunların esasında Tunahan tarafından mektup tarzında kaleme alınmış notlar/nasihatler/öğütler/bilgiler olduğu cemaat mensubu çok sayıda kişi tarafından ifade edilmiştir. Ancak bu ihtimal bizim kanaatimize göre eldeki metnin büyük kısmı için tutarlı gözükmemektedir. Zira eserin kapağında "Mektuplar” ifadesine yer verilmesi, bazı bölümlerin cevabî mektup karakteri taşıması, mektup üslubunu andıran çok sayıda dua ve temenniler ile bazı şahıs isimlerinin bulunması, söz konusu metnin büyük kısmının, gerçek kişilere yazılmış gerçek mektuplar olduğunu inkâra mahal bırakmayacak nitelikte ve çok açık biçimde ortaya koymaktadır. ${ }^{35}$

Mektuplar'ın gerçek kişilere yazılmış gerçek mektuplar olmayıp, mektup tarzında kaleme alınmış notlar kabul edilmesi halinde Tunahan'a nispet edilen eserin muhtevasında bulunan aşağıdaki ifadelerin, bu iddiaya uygun biçimde tevil edilmesi gerekecektir:

"Mektubunuzu memnuniyetle aldım" (Mektuplar, s. 9),

"Bayram-1 mübârekinizi en iyi temennilerimle bilmukabele tebrik ederim" (s. 58),

"Bir Mektuptan..." (s. 60),

"Vâlide-i muhteremenizin dâr-1 âhirete intikali haberini müş’ir olan mektubunuzu bu sabah kemâl-i hüzn ile aldım”36 (s. 109),

“29 Ramazan’da Vâsıl Olan Mektubun Bazı Parçaları” (s. 113),

"Rahmi Beye Yazılan Mektubun Bazı Kisımları" (s. 119) vb.

Görüldüğü gibi söz konusu ifadeler, tevile mahal bırakmayacak kesinlikte açık ve nettirler. Bu ifadeler ile özellikle bazı metinlerin baş ve son kısımlarında mektup

35 Ancak burada belirtilmesi gereken husus, gerek Oğuz'a gerek Tunahan'a nispet edilen eserdeki bazı bölümlerin aslında mektup değil, bir risâle olduğu hususudur. Örneğin; Tunahan'a nispet edilen eserlerden Kibrît-i Ahmer ismiyle basılan risâle ile Oğuz'a nispet edilen eserdeki "Muâmelât-1 Zâtiyye ve Sifâtiyye, Avâlim-i Mâddiyye ve Ma'neviyye" başlıkl1 10 numaralı mektup olarak yer alan bölüm aynı olup aslında bunlar müstakil bir risâle olmasına rağmen muhtemelen tek başına basılamayacak kadar küçük olduğu için Mektuplar'ın içine derc edilmiştir. Nitekim Bayburtlu, bunun farkında olduğunu, fakat yukarıda bahsedilen gerekçeden dolayı ilgili metni Mektuplar'ın içerisine aldığını ifade etmiştir. Aynı şekilde Tunahan'a nispet edilen eserde yer alan "Âdâb-1 Zarûriyye” başlıklı bölüm de (s. 146) aslında Oğuz’un Kitâbü Âdâbi’l-Mürîdîn isimli risâlesidir. Bunlar dışında Oğuz'un Mektuplar 'nndaki 8 numaralı mektup da aslında bir risâle mahiyetindedir.

36 Mustafa Bayburtlu'nun ifadesine göre bu mektupta vefatından bahsedilen kişinin Oğuz'un bağl1larından Rahmi Köseoğlu'nun annesi olması kuvvetle muhtemeldir. Nitekim daha sonra kendisine Rahmi Köseoğlu'nun annesinin vefat tarihini öğrenme imkânımız bulunup bulunmadığını sorduğumuzda şu cevabı göndermiştir: "Rahmi Beyamca'nın (Hüseyin Rahmi Köseoğlu) annesinin ismini ve vefât tarihini Nüfus Müdürlügü'nden öğrendik. İsmi: Fatma. Vefât tarihi: 26.01.1933. Doğum tarihi ise: 1868. Rahmi Bey'in intisâbı 1932'de tahakkuk ettiğine göre, “98” numaralı tâziye mektubunun kendisine yazıldığı anlaşıliyor."

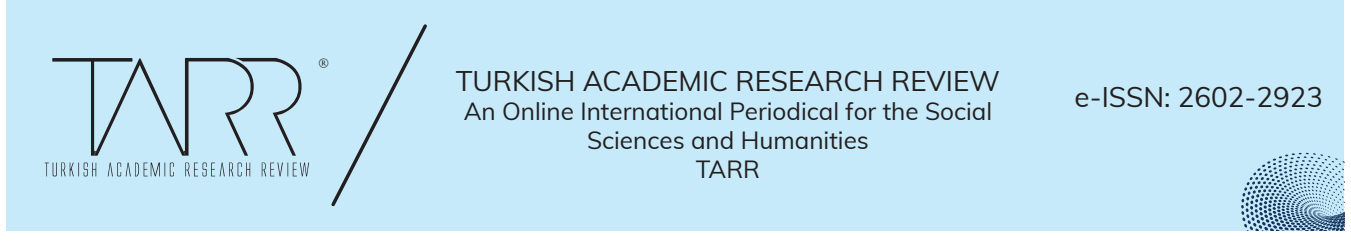


üslubunu andıran çok sayıda başka ifadeler, ${ }^{37}$ Mektuplar ve Bazı Mesâil-i Mühimme isimli eserin gerçek mektuplar olmayıp, mektup tarzında kaleme alınmış nasihatler ve ögütler olduğu şeklindeki izahı geçersiz kılmaya yetecek niteliktedir. Üstelik bu metinleri sahiplenen diğer taraf, bunların gerçek mektuplar olduğunu ifade etmekte ve yazıldığ kişilerin bir kısmının ismini de vermektedirler. Ayrıca bazı mektupların kendilerine yazıldığı söylenen zatları gören kişiler bugün hayattadırlar. Örneğin her iki tarafın bastığı ilk mektubun Rahmi Köseoğlu'na yazıldığını hem Oğuz'un varisleri ifade etmekte ${ }^{38}$ hem de Mektuplar'ı baskıya hazırlayan Bayburtlu, Rahmi Bey'e yazılan mektubun tarihinin de (10 Muharrem1351/16 Mayıs 1932) üzerinde yazılı olduğu bir nüshanın kendisinde bulunduğunu beyan etmektedir. Oğuz'un, mektuplar dişında bazı eserlerini/risâlelerini de istinsah edip bağlılarına gönderdiği bilinmektedir. ${ }^{39}$

Göz önünde bulundurulması gereken başka bir husus da Tunahan'ın takipçileri tarafından Mektuplar ismiyle basılan kitabın kapağında ve iç kısımlarında eserin Tunahan'a ait olduğunu bildiren herhangi bir ifadenin kullanılmamış olmasıdır. Şayet mektuplar ona ait ise, tabiî olanın bunun belirtilmesi olduğu aşikârdır. Nitekim onun Kur'ân Harf ve Harekeleri isimli “elifbâ"sının üzerine ismi yazılmıştır. İsminin tasrih edilmemesini de mektupların ona ait olmadığının ya da cemaat içerisinde o dönemde bu konuda bir şüphe bulunduğunun zımnî bir kabulü ve işareti olarak düşünmek mümkündür. Dönemin siyasi sıkıntılarından ve bask1larından kurtulmak için böyle bir yol izlendiği şeklinde dile getirilebilecek bir itiraz veya izah ise, günümüzde böyle bir sıkıntı olmadığı için en azından "Yeni baskılarında yazar ismine niçin yer verilmemektedir?" sorusunu akla getirmektedir. Tunahan'ın isminin üzerine açıkça yazılmamasına rağmen cemaat içerisinde eserin sözlü olarak ona nispeti, bilinen ve yaygın bir durumdur. Yani kapağında yazılı olarak açıkça Tunahan'a aidiyeti belirtilmeyen metnin, ${ }^{40}$ sözlü olarak ona

37 Örneğin; "Mademki siz rızâullâh için mahabbet esasına müsteniden benim ile arkadaşlığı talep ediyorsunuz ve geri çevrilmemenizi istiyorsunuz, ben de sizden benim için bu arkadaşlığa terettüb eden vazâif ve vecâibin mukaddimât-1 esâsiyesini bildiriyorum. Bunları hüsn-i telakkî ve idrâke muvaffakiyetinizi Mevlâ'dan dilerim" (s. 12); "Mademki sizinle aramızda nisbet-i mahabbet teessüs edecektir; benden göreceğiniz mukâbele ve hizmet, dâimâ hayât-1 ebediyye ve sermediyeye nâiliyyetinizin mevkûfun ileyhi olan ümûr ve husûsun ifade ve edâsı olacaktır (s. 19); "Mevlâ-yı müteâl sizleri dâimen tevfíkât-1 kâmilesine ve zâtî rızasına mazhar buyursun. Âmîn!” (s. 22); "Mevlâ-yı müteâl cümlemizi bu devletle müşerref olan zümre-i hâssu'l-hâssân meyânında mahşûr eyleye ve onların vâris ve tufeylîsi kıla. Âmîn!” (s. 40); "Mevlâ-yı müteâl... enbiyâ-yı mürselîne hâs olan hakîkî mahabbetin kemaline mazhar buyursun... Âmîn!" (s. 43); "Mevlâ-yı müteâl cümlemizi... müşerref kılsın..." (s. 65); Mevlâ-yı müteâlden... niyaz ederim" (s. 76). Bunlar dışında başka bazı ifadeler için bkz. s. 80, 83, 88, 91, 100, 108, 129 vd.

38 Nitekim Tunahan'ın Mektuplar'ında da “Rahmi Bey'e Yazılan Mektubun Bazı Kısımları” (s. 119) başlıklı bir bölüm bulunmaktadır.

39 Mustafa Bayburtlu'nun ifade ettiğine göre Rahmi Köseoğlu'na yazılan mektubun, üzerinde 10 Muharrem 1351 tarihinin de bulunduğu bir nüshası elinde mevcuttur. Bu tarih, miladi takvime göre 16 May1s 1932 tarihine tekabül etmektedir. Kütükte ise Hayri Taptık tarafindan tarih not edilmemiştir. Rahmi Köseoğlu'nun bugün hayatta akrabası kalmadığı için kendisine gönderilmiş mektupların asıl nüshalarının akıbetinden haberdar değiliz.

40 Mektuplar ve Bazı Mesâil-i Mühimme ismiyle basılan eserin müellifini belirtir kısımda sarâhaten Süleyman Hilmi Tunahan'ın ismi yazılmamıştır. Kapağında «Bu(nu yazan), İmâm Rabbânî'nin evlâdından Salâhuddîn İbn Mevlânâ Sirâcüddîn'dir" ya da "Bu(nu yazan), İmâm Rabbânî (ve) Salâhuddîn İbn Mevlânâ Sirâcüddîn'in evlâdından birisidir" anlamlarına gelebilecek "Hâzâ min evlâdi'l-İmâm er-Rabbânî Salâhuddîn İbn Mevlânâ Sirâcüddîn” şeklinde Arapça gramer açısından problemli bir ibare

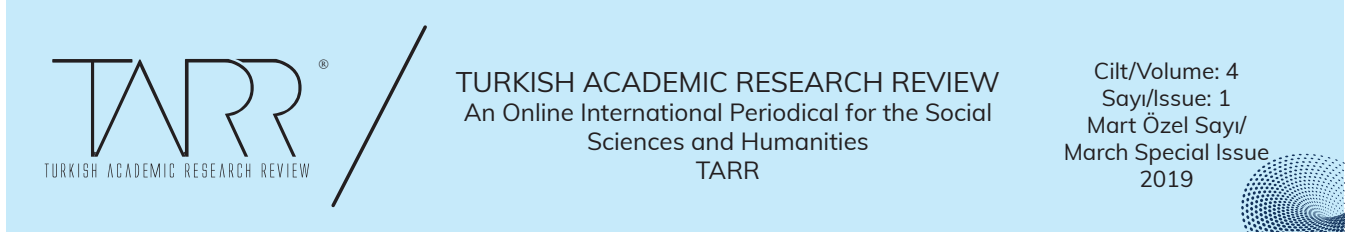


ait olduğunu belirtmekte bir sakınca görülmemektedir. Mektuplar'ın Tunahan'a ait olduğu cemaat içi sözlü naklin yanı sıra aralarında cemaatin yayınevinden çıkan bazı eserlerin de bulunduğu birçok yazılı kaynakta da mevcuttur. ${ }^{41}$ Ayrıca Oğuz'un Mektuplar'ı basılmış, herkesin istifadesine ve erişimine açık iken Süleymanlı Cemaatinin Osmanlı Türkçesi ile bastığı eserin dağıtımı yalnızca cemaat içerisinde -ve belli bir zümreye- yapılmaktadır.

Süleymanlı Cemaatinin geçmişte çıkardığı haftalık Ufuk gazetesi ile günlük Sabah gazetesinde Tunahan'ın basılmıs tek eseri olarak Kur'an Harf ve Harekeleri isimli "elifbâ" zikredilmektedir. Örneğin Ufuk gazetesinin 15 Haziran 1979 tarihli 508. sayısında “Süleyman Efendi (k.s.) Hazretlerinin tek matbu eseri bu!” yazısıyla onun "elifbâ"sına yer verilmektedir. Aynı yerde Tunahan'ın ilm-i akâide dair bir eser yazdırmaya başlayıp bilahare bundan vazgeçtiği ve talebelerinin ısrarı üzerine,

"Evladım ısrar etmeyiniz. Duydum ki bazıları, hocalarının eserlerini (hâşâ) Kur'ân-1 Kerîm'den üstün tutuyorlarmış. İleride Efendi Hazretlerinin Akâid kitabı diye benim evladlarım da böyle bir derekeye düşerler mi düşüncesiyle

konulmuştur. Tunahan'ın tarikat silsilesinde mürşidi, Salâhuddîn İbn Mevlânâ Sirâcüddîn olarak verilmektedir (Fazilet Neşriyat Araştırma Heyeti, Silsiletü'z-Zeheb Silsile-i Sâdât-ı Nakşibendiyye, 5. bs., İstanbul: Fazilet Neșriyat, 2017, 20; 352. Dedeoğlu, Abdülkadir, Silsile-i Sâdât-ı Nakşibendiyye-i Aliyye, 2. bs., İstanbul: Osmanlı Yayınevi, 27; Bkz. Hocazâde Ahmed Hilmi, Hadîkatü 'l-Evliyâ (Tercüme: Veliler Bahçesi), İstanbul: Osmanlı Yayınevi, 1979, 148). Veliler Bahçesi ismiyle basılan bu tercüme eserde Hadîkatü'l-Evliyâ 'nın aslında olmayan (Bkz. Hocazâde Ahmed Hilmi, Hadîkatü'l-Evliyâ, İstanbul: 1318, 165-174) bazı isimler ilave edilerek Süleyman Hilmi Tunahan silsileye dahil edilmiştir. Bkz. Mustafa Kara, "Hocazâde Ahmed Hilmi", Türkiye Diyanet Vakfi İslâm Ansiklopedisi, (İstanbul: TDV Yay., 1998), 18: 207. Salâhuddîn'in torunun torunu Madınabonu Moıdınova ile yaptığımız görüşmede onun babasının Mevlânâ Sirâcüddîn değil, Mevlevî Sirâcüddîn lakabıyla bilindiğini ifade etmiştir. Salâhuddîn hakkında Madınabonu Moıdınova tarafindan 2018 yılında Uludağ Üniversitesi Sosyal Bilimler Enstitüsü'nde "Sâkıb Salahaddîn'in Dîvân'ı ve Tasavvufî Görüşleri” başlıklı bir yüksek lisans tezi hazırlanmıştır. Salâhuddîn İbn Mevlânâ Sirâcüddîn için Bkz. Necdet Tosun, "Selâhaddîn Sâkıb", Türkiye Diyanet Vakfi İslâm Ansiklopedisi, (İstanbul: TDV Yay., 2016) Ek-2: 498.

Kapağında yer alan bu ifadelerden yola çıkılarak Mektuplar ve Bazı Mesâil-i Mühimme isimli eserin Salâhuddîn İbn Mevlânâ Sirâcüddîn'e ait olduğu sanılabilir ya da iddia edilebilir. Ancak bu, tarihî açıdan imkânsızdır. Zira eserin içerisinde bazı mektupların yazım zamanını bildiren tarihler Salâhuddîn'in vefat tarihi olan 1910'dan sonradır. Örneğin eserin ilk bölümünün tarihi 10 Muharrem 1340 yani 13 Eylül 1921'dir (s. 22). Yine “Temessük-ü Hakîkî” başlığını taşıyan mektup 23 Şaban 1341 yani 10 Nisan 1923 tarihlidir (s. 31). 1910'da vefat eden birinin 1921 ya da 1923 yılında mektup veya risâle yazması ise imkânsızdır. Ayrıca eserin dili saf ve ağır Anadolu Türkçesidir. Salâhuddîn ise Özbek'dir. Bugün Kırgızistan sınırları içinde kalan Oş şehrinde dünyaya gelmiştir. Eserin dilinde Özbek ya da Kırgız Türkçesinden hiçbir unsur bulunmamaktadır. Üstelik varisleri tarafından onun böyle bir eseri olduğu da kabul edilmemektedir. Dolayısıyla böyle bir iddia ya da izah kesinlikle ihtimal dahilinde değildir.

41 Mesela bkz. Fazilet Neşriyat Araştırma Heyeti, Silsiletü'z-Zeheb Silsile-i Sâdât-ı Nakşibendiyye, 5. bs., İstanbul: Fazilet Neşriyat, 2017, 356; Önser Yeğin, Süleyman Hilmi Tunahan ve Tasavvufí Şahsiyeti, (Lisans Bitirme Tezi, Dokuz Eylül Üniversitesi, 1996), 76. Yeğin burada bu eserlerin bizzat Süleyman Hilmi Tunahan tarafından kaleme alınıp alınmadığı konusunda kesin bir bilgiye ulaşamadığını kaydeder. Emre, Mehmed, Üstâdım Süleyman Hilmi Tunahan ve Hâtıralarım, 3. bs., İstanbul: Erhan Yayınları, 2003, 39; Akgündüz, Ahmed, Arşiv Belgeleri Işı̆̆ı̆da Silistre'li Süleyman Hilmi Tunahan, İstanbul: Osmanlı Araştırmaları Vakf1, 1997, 97-98; Akgündüz, Ahmed, Tabular Yıkıllyor-2, 7. bs., İstanbul: Osmanlı Araştırmaları Vakfı, 2007, 110; Târık Abdülcelil es-Seyyid, el-Harekâtü'l-İslâmiyye fì Türkiye el-Muâsıra, Mısır: Cevâdü'ş-şark li'n-neşr ve't-tevzî', 224. Süleymanlı Cemaatinin Tunahan'a nispet ettiği, fakat bizim Oğuz'a ait olduğunu tespit ettiğimiz Kibrît-i Ahmer isimli risâle de Türkiye Diyanet Vakfı İSAM Kütüphanesi kataloğunda 297.4 TUN.R 1330 numarası ile Süleyman Hilmi Tunahan adına kaydedilmiştir.

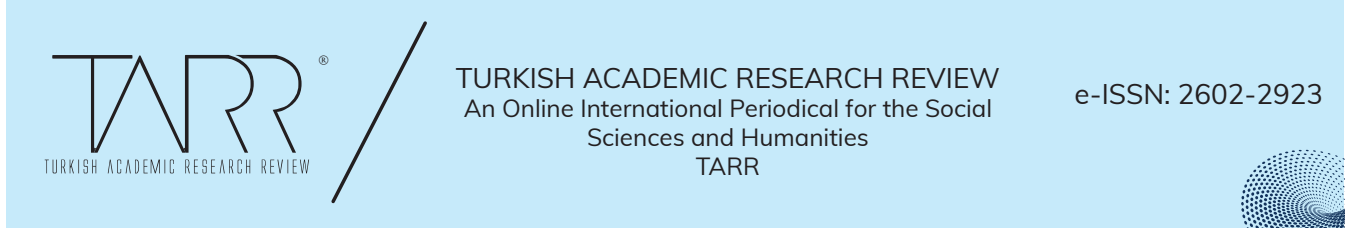


(bu işten) sarf-1 nazar ettim. Yazdırmayacağım. Esasen yazılmayan bir şey de kalmamıştır."

cevabını verdiği kaydedilmiştir. ${ }^{42}$ Devamında "Bununla beraber tasavvufa dair yazdığı çeşitli eserlerini(n) hayatında bastırılmasına müsaade etmemiştir” ifadeleri mevcuttur. Burada bahsedilen eserlerle muhtemelen daha sonra basilan ve bu makalenin konusu olan Mektuplar ile Kibritt-i Ahmer ve İksîr-i Ulûm risâleleri kastedilmektedir. Zira Ufuk gazetesinin 6 Eylül 1978 tarihli 474. sayısında

"Efendi Hazretlerinin (k.s.) Sülûk için Maârif-i Aliyye adında bir risalesi eski Şuhud müftüsü Mehmet Aksoy (Ahbap Dayı) tarafından teksir edilerek talebelerine dağıtılmıştı"”

denilerek $^{43}$, söz konusu risâlenin ilk sayfasının resmi paylaşılmıştır. Bahsi geçen resimdeki yazı, Tunahan'ın Mektuplar'ının aslını teşkil eden, bizim de elimizde bir nüshası bulunan el yazısı ile uyuşmaktadır.

Ufuk gazetesinin 9 Kasım 1977 tarihli 431. sayısında A. Fazıl Temizerler ile yapilan bir röportajda ise "O'na 'Niye eser yazmıyorsun?' diyene O, 'Ben canlı eser yetiştiriyorum' derdi” denilmektedir. ${ }^{44}$

Öte yandan “Niçin kitap yazmadınız?” sorusuna Tunahan'ın;

"Selefin mum 1şığında yazdığı paha biçilmez hazine misali eserlerin toprağa gömülerek çürüdüğünü, bakkallara satılarak çöplüklerde çiğnendiğini, bir kısmının da kütüphane raflarında tozlanmış ve çürümeye terk edilmiş olduğunu gördüm. Medreseleri kapanmış, yazısı değiştirilmiş, din ilimleri yok olmaya yüz tutmuş olan bir zamanda, kitap yazmaktansa, yazılan ilmî eserleri anlayarak anlatacak ve ilmi satırdan sadra intikal ettirip yaşatacak talebe, yani canlı kitap yetiştirmeyi daha lüzumlu buldum." ${ }^{45}$

cevabı da dikkate alınması gereken bir husustur. Onun Kur'ân Harf ve Harekeleri isimli bir "elifbâ'sı olduğu kesin olarak bilindiğine göre bu sorunun "Niçin (başka) kitap yazmadınız?” şeklinde düşünülmesi daha uygundur.

Her durumda Mektuplar adlı esere Tunahan'ın isminin açıkça yazılmaması, üzerinde durulması ve cevap verilmesi gereken önemli bir meseledir.

\section{Değerlendirme}

Oğuz'a nispet edilen mektupların tamamı olmasa da bir kısmının Oğuz tarafından kimlere yazıldığı bilinmektedir. Bu kişilerin bir kısmı Oğuz’un müntesipleri

42 Ufuk, (Haftalık Siyasî Gazete), 15 Haziran 1979, sayı: 508, 8.

43 Ufuk, (Haftalık Siyasî Gazete), 6 Eylül 1978, sayı: 474, 7.

44 Ufuk, (Haftalık Siyasî Gazete), 9 Kasım 1977, sayı: 431, 6.

45 Fazilet Neşriyat Araştırma Heyeti, Silsiletü'z-Zeheb Silsile-i Sâdât-ı Nakşibendiyye, 5. bs., İstanbul: Fazilet Neşriyat, 2017, 355; Yeğin, Süleyman Hilmi Tunahan ve Tasavvufí Şahsiyeti, 76-77. Akgündüz, Silistre'li Süleyman Hilmi Tunahan, 98; Akgündüz, Tabular Yıkıllyor-2, 111. Aslında bu iki ifade Süleyman Hilmi Tunahan'ın “elifbâ” dışında başka eser yazmadığını ortaya koymaktadır. Temizerler'in ifadesine göre röportajın tarihi olan 1977 'de cemaat içerisinde onun başka eser kaleme almadığı düşüncesi hakimdir.

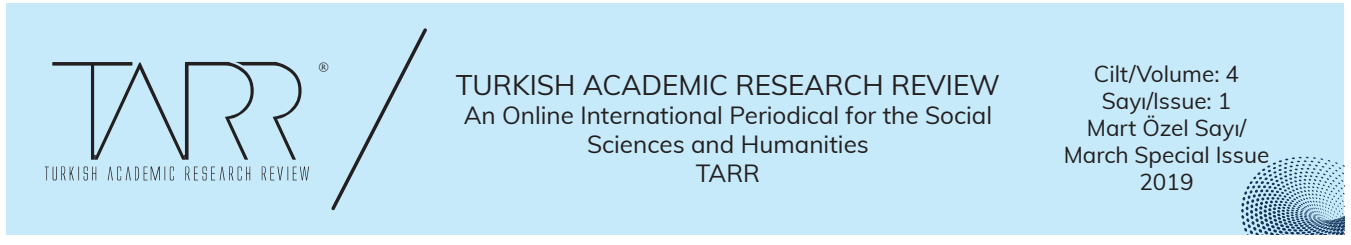


iken, bazıları dönemin önde gelen ilim adamlarıdır. Hayri Taptık'ın kaleme aldığ kütükler üzerinde yapılacak detaylı bir araştırma ya da mektupların asıllarına ulaşılması, en azından mektupların bir kısmının kime yazıldığını ortaya çıkarabilir. Buna karşın Tunahan'a nispet edilen eserde yer alan mektupların, onun tarafından kimlere yazıldığı hakkında hiçbir bilgiye ulaşılamamıştır. Tunahan'ın, talebelerinden ya da sevenlerinden birine veya birkaçına mektup yazmış olduğu kabul edilecek olursa, bu mektubun bir iftihar vesilesi olarak yazıldığı kişi tarafından gizlenmemesi ve muhafaza edilmesi gerektiği açıktır. Ancak ne vefat etmiş ne de hayatta olan talebelerinin hiçbirisinden onun kendilerine söz konusu mektuplardan yazdığına dair bir nakle ulaşılamamıștır.

\section{Mektuplar ve Kibrît-i Ahmer'in Yazım ve Basım Tarihleri ile Takipçilerine İntikal Süreci}

\subsection{Mektuplar'ın Yazım ve Basım Tarihi ve İntikal Süreci}

Oğuz Yayınları'ndan çıkan Muhammed İhsan Oğuz'dan Mektuplar isimli eserin ilk baskısı 1994 yılında yapılmıştır. Mektuplar'ın büyük kısmının kendisine dayanılarak basıldığı ((kütük) tabir edilen üç ciltlik asıl nüshanın Hayri Taptık tarafından yazılmaya başlandığ 1 tarih ise kesin olarak bilinmemektedir. Mustafa Bayburtlu ve Oğuz'un varislerinin tahminlerine göre Hayri Taptık'ın mektupları bu defterlerde istinsah etmeye başladığ 1 tarih 1930'lu yıllar olmalıdır. Zira hem Mektuplar ve Bazı Mesâil-i Mühimme ismiyle Süleymanlı Cemaatinin bastığı eserde hem de Muhammed İhsan Oğuzdan Mektuplar ismiyle Oğuz Yayınları tarafından basılan eserde yer alan birinci mektubun yazım tarihi, Mustafa Bayburtlu'da bulunan başka bir nüshanın üzerinde yazdığına göre 10 Muharrem 1351/16 Mayıs 1932'dir. Rahmi Köseoğlu'nun Hayri Taptık'in delalet ve tavassutu ile İhsan Oğuz ile tanıştığı ${ }^{46}$ Oğuz'un torunu Mehmet İhsan Oğuz'un ifade ettiğine göre Hayri Bey'in 1934 tarihinde Kastamonu'da İhsan Oğuz'u ziyaret ettiği dikkate alınırsa Hayri Bey'in 1930'lu yıllarda bugün elde bulunan kütügü istinsah etmeye başlad1ğ1 tahmin edilmektedir. Nitekim Bayburtlu, Rahmi Köseoğlu'ndan dinlediği bazı hatıralardan yola çıkarak Hayri Taptık'ın İhsan Oğuz ile 1920'li yıllarda tanışmış olduğunu tahmin etmektedir. Fakat yukarıda da işaret ettiğimiz gibi (18 numaralı dipnot) İstanbul Büyükşehir Belediyesi Atatürk Kitaplığı Osman Ergin yazmaları O.E.1813 numaralı Vahdet-i Vücûd ve Vahdet-i Şühûd Münakaşaları isimli yazma eserde yer alan 17 Mart 1920 tarihli Oğuz’a ait mektubun baş kısmındaki;

“Hayri Bey Efendi’ye takdim etiğim bazı âsârın mütâlaasından hasıl ettikleri intıbââtı mutazammın yazılarınızı minnetle ahz ve mütâlaa eyledim.” (s. 15)

46 Nitekim bu husus, Oğuz’un ilk mektubunun içerisinde onun Rahmi Köseoğlu'nun nispet talebine verdiği cevapta «Hayri Bey tarafından şahsınız hakkınızda vâki' iş’ârâtı da nazar-1 i'tibâra alarak..." (Oğuz, Mektuplar, I: 337) şeklinde ifade edilmiştir. Hayri Taptık kütükte, kendi isminin yazdığı yeri noktalar (...) koyarak geçmiştir. Mustafa Bayburtlu daha sonra buradaki ismin "Hayri Bey" olduğunu mektubun kendisine yazıldığı Rahmi Köseoğlu'ndan öğrenerek noktaların olduğu yere onun ismini yazmıştır. Bu ifade Süleymanlı Cemaatinin bastığı Mektuplar 'da "Hayri Bey tarafından” kısmı olmadan yer almaktadır (Mektuplar ve Bazı Mesâil-i Mühimme, 9).

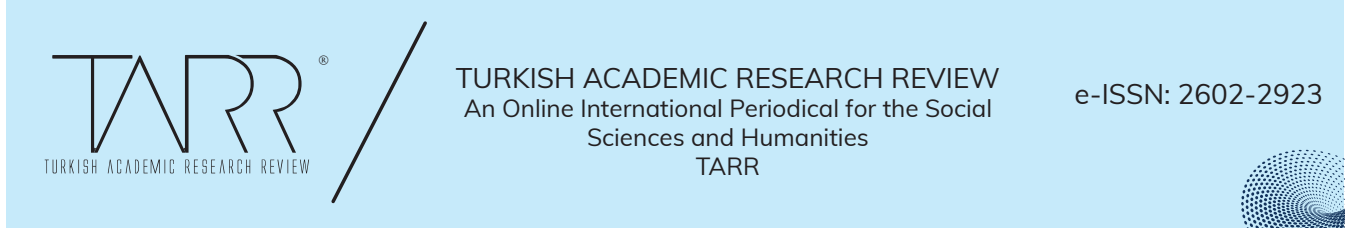


yazısından tespit ettiğimize göre Taptık'ın Oğuz ile tanışıklığı 17 Mart 1920'den öncesine dayanmaktadır. Taptık'ın kütükleri istinsah etmeye başladığı tarihi kesin olarak tespit etmemiz mümkün olmamakla birlikte, ilk mektubun Oğuz tarafından kaleme alındığı tarihin 10 Muharrem 1351/16 Mayıs 1932 olması göz önünde bulundurulursa her durumda kütüklerin yazılmaya başlandığ 1 tarihin bu tarihten (16 Mayıs 1932) sonra olması gerekmektedir.

Hayri Taptık 1968 yılında vefat etmiştir. Onun, istinsah ettiği mektupları Rahmi Köseoğlu'na teslim ettiği tarih tam olarak tespit edilememiştir. Taptık'ın vefat tarihinin 1968 olduğu ve bu tarihten birkaç sene önce Köseoğlu'na teslim etmiş olduğu kabul edilirse yaklaşık bir tahmin yürütülebilir. Köseoğlu'nun Çubukçu'ya teslim ettiği tarih ise bir-iki senelik yanılma payı ile birlikte 1970'dir. Rahmi Köseoğlu'nun bugün hayatta akrabası kalmadığı için söz konusu mektubun asıl nüshasının akıbeti hakkında şimdilik bir bilgi sahibi değiliz. Kütükler Çubukçu'nun vefat tarihi olan 2015 yılından birkaç yıl önce Oğuz Vakfı'na intikal etmiştir.

Tunahan'a nispet edilen Mektuplar, tespit edebildiğimiz kadarı ile Osmanlı Türkçesi ile kaleme alınmış birtakım nüshalar bir araya getirilerek basılmıştır. Bizim de elimizde bulunan fotokopi nüshalar üzerine sonradan "Bu yazı babamın (Mustafa Arıkan) yazısı. Hasan Arıkan”, "Lütfi Davran'dan gelen”, "Biletçi Mehmet Efendi” (Mehmet Akçelioğlu) notları düşülmüştür. Adı geçen kişiler Tunahan'ın önde gelen talebeleridirler. Eğer bu notların içerdiği bilgi doğru ise eldeki kitabın, onlardan gelen nüshalara dayanılarak basıldığını söylemek mümkündür. Fakat söz konusu nüshaların onlara bizzat Süleyman Hilmi Tunahan'dan mı, yoksa bir başkasından mı intikal ettiğine dair kesin bir bilgiye ulaşmamız mümkün olmamıştır. Kanaatimize göre söz konusu el yazması notların Tunahan'dan bu kişilere intikal etmiş olması mümkün değildir. Zira bu isimlerin kendilerinden bu yönde bir nakil bulunmamaktadır. Diğer yandan Tunahan'ın diğer talebelerinden de bu şekilde bir nakil mevcut değildir.

Süleymanlı Cemaatinin bastığg Mektuplar ve Bazı Mesâil-i Mühimme isimli eserin üzerinde basım tarihi ve yeri bulunmamaktadır. Edindiğimiz bilgilere göre cemaat içerisinde herkese olmasa da belli kişilere 1980'lerin sonuna doğru Mektuplar'ın verilmeye başlandığını kesin olarak söyleyebiliyoruz. Basım tarihinin daha erken bir tarih olması da mümkün olmakla birlikte cemaat tarafindan Mektuplar ve Bazı Mesâil-i Mühimme isimli eserin ilk defa hangi tarihte basıldığını kesin olarak tespit etmemiz mümkün olmamıştır. Buna rağmen Ufuk gazetesinin 6 Eylül 1978 tarihli 474. sayısında Tunahan'ın talebelerinden Mehmet Aksoy'un (Ahbap Hoca) teksir edip talebelerine dağıttığı ifade edilen, bizim de elimizde fotokopisi bulunan Mektuplar'ın asıl nüshasının ilk sayfasına yer verilmesi, cemaat içerisinde söz konusu mektupların -en azından belli bir kesim tarafından- bilinirliğinin 6 Eylül 1978 yılından öncesine dayandığını kesin olarak ortaya koymaktadır. Mektuplar ve Bazı Mesâil-i Mühimme 'nin basılmasını Süleyman Hilmi Tunahan'ın vefat yılı 1959'dan 2000 yılına kadar cemaatin liderliğini yapmış olan damadı Kemal Kacar'1n (ö. 2000) istediği ve onun, içerikte bulunan bazı isimleri müstear isim olarak ifade ettiği Süleymanlı Cemaatinde Mektuplar' 1 bas-

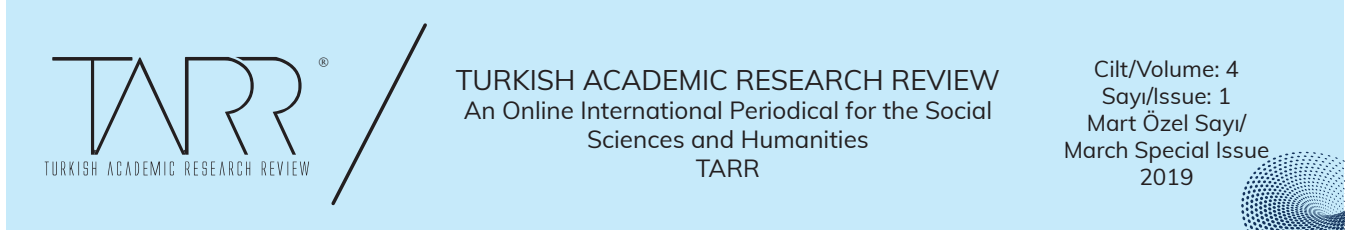


kıya hazırlayan kişiler tarafından belirtilmiştir. Ancak daha önce de belirttiğimiz gibi bu şekilde bir açıklama tatmin edici değildir. Zira Oğuz tarafında bu isimler ve eserler müsteâr/hayâlî değil, gerçek kişi ve eserlere tekabül etmektedir. Diğer taraftan Kemal Kacar'in bu eseri Tunahan'a nispet etmeden okunmasinı tavsiye ettiği, bu isnadın daha sonra başkaları tarafından yapıldığını ifade edenler de olmuştur. Dolayısıyla Kacar'a isnad edilen yukarıdaki açıklama tashihe muhtaçtır.

Bununla birlikte Süleymanlı Cemaatinin yayınevi Fazilet Neşriyat'ta Tunahan'ın Mektuplar'ının ya da Kibrît-i Ahmer isimli risâlenin bir ya da birden fazla el yazmasının bulunduğu yönünde ulaştığımız bir bilgiyi teyit edemediğimizi de belirtmemiz gerekmektedir. Konuyla ilgili görüşme talebimize Fazilet Neşriyat'tan olumlu bir cevap alınamamıştır. Şayet var ise bu nüshalar bizim elimizdeki nüshalar olabileceği gibi başka nüshalar da olabilir. Daha önce de belirttiğimiz gibi Oğuz'un eserleri, bazılarını bu araştırma sırasında tespit ettiğimiz çok sayıda kişi tarafından istinsah edilmiştir. Bu açıdan Fazilet Neşriyat'ta ya da başka yerlerde bu eserlerin nüsha ya da nüshalarının bulunması çok uzak bir ihtimal değildir.

\subsection{Kibrît-i Ahmer İsimli Risâle'nin Yazım ve Basım Tarihi ve İntikal Süreci}

Süleymanlı Cemaati tarafından basılan Kibrît-i Ahmer tabir edilen risâle, Oğuz'un Mektuplar'ında "Muâmelât-1 Zâtiyye ve Sifâtiyye, Avâlim-i Mâddiyye ve Ma'neviyye” başlı̆̆1 ile mevcuttur (Mektuplar, I: 368-385). Kibrît-i Ahmer isimli risâlenin devamında yer alan İksîr-i Ulûm ve Ma'rifet risâlesi ise Oğuz Vakfı tarafından henüz basılmamıştır. Bu risâle, varislerinin ve Oğuz vakfı yöneticilerinin ifade ettiğine göre Oğuz’un baskıya hazırlanan diğer eserleri arasındadır.

İçerisinde İksîr-i Ulûm ve Ma'rifet isimli bir risâlenin de bulunduğu Risâle-i Kibrît-i Ahmer'in basım tarihinin, Mektuplar ve Bazı Mesâil-i Mühimme'nin basımından daha önce olduğu bilgisine ulaşmış bulunuyoruz. Edindiğimiz bilgilere göre bu risâle, Süleymanlı Cemaati tarafından h. 1400 yılında 1400 adet basılmıştır. Söz konusu tarih, miladi takvime göre 1980 yılına tekabül etmektedir. Görüştüğümüz başka bazı kişiler de yaklaşık olarak bu tarihlerde risâlenin basılmış olduğunu ve kendilerinin de o tarihlerde eseri gördüklerini teyit etmişlerdir.

Kibritt-i Ahmer'in üzerinde yazan tarih her ne kadar 1330'u işaret etse de eserin gerçekte bu tarihte basılmış olması imkânsızdır. Zira eserin üzerindeki tarih yaklaşık olarak 1912 yılına tekabül etmektedir. Bu tarihte Oğuz 25, Tunahan 24 yaşındadır. Her ikisinin de bu tarihte ve bu yaşlarda herhangi bir eser kaleme aldıkları bilinmemektedir. Eserin basılmış olabileceği tarihlerde ve sonrasında Tevhîd-i Tedrîsât Kanunu sebebiyle Arapça ve Osmanlı Türkçesinin öğretimi üzerindeki siyasî baskı ve yasaklardan dolayı eski bir tarihin, adı geçen eserin üzerine kaydedilmiş olması mümkündür. Bu uygulamanın söz konusu dönemde resmî takibattan kurtulmak için sıkça başvurulan bir yöntem olduğu bilinmektedir.

Kibrît-i Ahmer isimli risâlenin basım yeri olarak Şirket-i Mürettibiyye Matbaası gösterilmiştir. ${ }^{47} \mathrm{Bu}$ isimde bir matbaanın bulunduğu ve burada birçok eserin ba-

47 Şirket-i Mürettibiyye Matbaası: “Üsküdar Arabzade Mahâllesi'nde sâkin Artin Asadoryan tarafindan, rûmî 3 Temmuz 1305 (miladi 15 Temmuz 1889) tarihinde kurulan, Türkçe, Arapça, Fransızca, Ermenî-

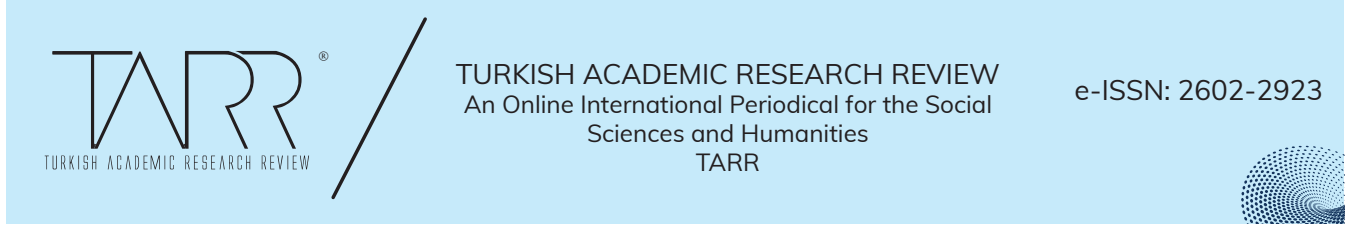


sıldığı bilinmektedir. Ancak söz konusu matbaada bu isimde bir eserin gerçekten basılmış olması imkân dâhilinde gözükmemektedir. Zira eserin gerçekte 1400 tarihinde, yani 1980 yılında basıldığı bilgisi doğru ise bu tarihte bu isimde faal halde bir matbaa bulunmamaktadır. Bu durumda, eserin tarihi gibi basım yeri de resmî takibattan kurtulmak için bir önlem olarak bu şekilde kaydedilmiş olmal1dir.

Diğer taraftan Süleyman Hilmi Tunahan'dan sonra 17 Haziran 2000'e kadar cemaatin liderliğini yapmış ve aynı zamanda onun damadı olan Kemal Kacar 1977 tarihli olduğu tahmin edilen bir sohbete ait ses kaydında:

“'Elâ lehu'l-halku ve'l-emru...' buyurduğu... 'elâ lehû âlem'ul-halk', 'elâ lehû-âlemu'l-emr' demek olduğu anlaşıllyor, karîne ile... 'Elâ lehu'l-halku ve'l-emru' dedikten sonra hemen ne buyuruyor? 'Tebârekellâhu rabbü'l-âlemîn. Âlemlerin Rabbi olan Allâhü Zülcelâl Hazretleri mütebârek oldu. İşte bu karîne ile anlıyoruz ki, o 'Halk' ve 'Emir Allâh'ındır' denildiği zaman, 'âlem-i halk', 'âlem-i emir' demek... Nitekim bunun tafsilatını Üstazlar1mız, bizlere mübarek fem-i saâdetlerinden naklettiler. Kitaplarda da gördük. Risâlelerinde de yazmışlar. En mükemmel şekilde Hazret-i Üstazımız, Risâlesi'nde 'âlem-i halk'a', 'âlem-i emr'e' ait, malumat var. Şimdiye kadar hiçbir tasavvufî eserde görülemeyecek derecede... Demek ki zamanı gelmiş, Hazret-i Allah yazdırmış, söylettirmiş, var orda... Ama, İmâm-1 Rabbânî Müceddid-i elf-i sânî Ahmed-i Fâruki-i Serhendî Hazretleri'nin Mektubât-ı Şerîfe'sinde de, birinci cildi ve ikinci cildinin muhtelif yerlerinde, âlem-i halk'a, âlem-i emr'e ait, malumat yine hayli var. Hazret-i Üstaz'in Risâlesi’nde olduğu gibi...”

demektedir. Kemal Kacar'in bu ifadelerinden anlaşıldığına göre o, Tunahan'ın "elifbâ" dışında başka eserlerinin olduğu görüşündedir. Fakat söz konusu eserlerin bizzat Tunahan'dan $\mathrm{m} ı$ alındığı yoksa başka birisinden alınarak daha sonra mı ona nispet edildiğine dair bir bilgiye ulaşılamamıştır. ${ }^{48}$ Ses kaydında bahsedilen konu Kibrît-i Ahmer isimli risâlede geçmektedir. Dolayısıyla Kemal Kacar'ın konuşmasında işaret ettiği risâle Kibrît-i Ahmer olmalıdır.

\section{Değerlendirme}

Mektuplar ve Bazı Mesâil-i Mühimme ismiyle Süleymanlı Cemaati tarafından basılan eserin 1980’li yılların sonlarına doğru basılmış ve belli kişilere dağıtılmış halde olduğu kesin olarak anlaşılmıştır. Bununla birlikte Ufuk gazetesinde yer alan açıklamalar ve orada Mektuplar'ın aslını teşkil eden nüshanın suretinin verilmesi, bu mektupların en azından bir kısım cemaat mensupları tarafından 1978'den

ce, Rumca, İtalyanca, İngilizce, Almanca neşriyat yapan ve Cağaloğlu'nda kaim bir matbaadır. Artin Asadoryan'nın, adının geçtiği birden çok matbaası mevcuttur. Artin Asadoryan ve mahdumları matbaası, Artin Asadoryan matbaası bunlardandır. Bunların, aynı matbaanın isim değişikliği mi yoksa farklı matbaalar mı olduğu malumumuz değildir" (https://dunyasozluk.com/baslik/\%C5\%9Firket-i+m\%C3\%BCrettibiye + matbaas $\% \mathrm{C} 4 \% \mathrm{~B} 1$, erişim: 11.01.2019). Alıntıda bulunan bazı yazım hataları tarafımızdan düzeltilmiştir.

48 Ayrıca akla gelen başka bir soru da Tunahan'ın vefat tarihi olan 1959 ile sohbetin kaydedildiği tahmin edilen 1977 yılları arasında eserin neden bilinmediği ya da ortaya çıarılmadı̆̆ıdır.

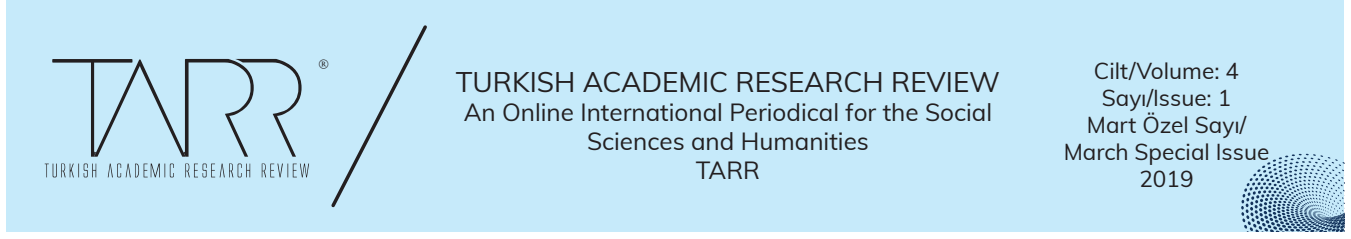


önce bilindiğini göstermektedir. Kacar'n ses kaydına göre bu tarihi 1977’ye kadar geriye götürmemiz mümkündür. Cemaatin Kibrît-i Ahmer ismiyle bastığ1 ve üzerinde 1330 tarihi bulunan risâlenin gerçek basım tarihinin ise h. 1400/m. 1980 olduğu tespit edilmiştir. İçerisinde Kibrît-i Ahmer'in de bulunduğu Oğuz Yayınları tarafından Muhammed İhsan Oğuz'dan Mektuplar isimli eserlerin basım tarihi ise 1994'tür. Ancak bu mektuplar Oğuz'un sevenleri tarafından çok daha eski tarihlerde bilinmektedir. Ayrıca Oğuz'un mektuplarının büyük kısmına asıl teşkil eden Hayri Taptık'in mektupları ve risâleleri, gönderildikleri kişilerdeki asıllarından (ilk mektubun tarihine göre 1932'den sonraki) 1930'lu yıllarda istinsah etmeye başladığ 1 tahmin edilmektedir. Oğuz'un mektuplarını ve diğer eserlerini Taptık dışında istinsah eden kişilerin bulunduğu da araştırmamız sırasında tespit edilmiştir. ${ }^{49}$

Bu bilgilere göre hem Mektuplar'ın hem de Kibrit-i Ahmer'in basım tarihi itibarı ile önceliğinin Tunahan'a isnad edilen eserlere ait olduğu kesindir. Ancak her iki taraftaki baskılara asıl teşkil eden eldeki el yazması nüshaların ilk kaleme alındıkları tarih itibarı ile önceliği Oğuz’a isnad edilene aittir. Yani her ne kadar her iki kitabı ilk önce Süleymanlı cemaati basmış olsa da Oğuz'un kitabının kendisine dayandığı el yazması nüshanın tarihi çok daha eskidir.

\section{Eserlerin İçeriklerinde Kime Ait Olduklarını Ortaya Koyan Bazı Ifadeler}

Mektuplar'in ve Kibrît-i Ahmer ismiyle basılan risâlenin içerisinde bulunan bazı ifadeler, eserlerin gerçekte kime ait olduğuna yönelik deliller ve ipuçları sunmaktadir. ${ }^{50}$

1. Süleymanlı Cemaatinin bastığı Mektuplar ve Bazı Mesâil-i Mühimme isimli eserde,

“Benim tarikatte Hazret-i Fahr-i âlem ve Cenâb-1 Hâlik-1 âlem'e olan nispet-i irtibât ve intisâb-1 hâssım kutbü'l-evliyâi'l-vâsılîn, gavsü'l-küberâi'l-muhakkikîn, mevrid-i evsâf ve ahlâk-1 ilâhî, vâris-i tâm ve ekmel-i Muhammedî, şeyhunâ ve mürşidünâ es-Seyyid Ahmed el-Kürdî el-Hüseynî (radiye anhu'l-Bârî) Hazretlerinden itibaren 33 vasita ile müselsel ve muttasıldır."

ifadeleri mevcuttur (s. 12).

Görüldüğü gibi Süleymanlı Cemaatinin basmış olduğu Mektuplar'da, eserin sahibinin mürşidi, es-Seyyid Ahmed el-Kürdî el-Hüseynî ${ }^{51}$ (ö. 1921) olarak verilmiştir.

49 Oğuz'un bazı eserlerini istinsah edenlerden biri Osman Nuri Ergin'dir. Ergin, Oğuz'un kitabındaki «Mi'râc-1 Muhammedî” başlıklı 57. mektubu (I: 473-477) “İhsan Bey’in İzmirli İsmail Hakkı Bey’e Bir Mektubu" başlığı ve 20 Kânûn-1 Evvel 1932 tarihi ile istinsah etmiştir (İstanbul Büyükşehir Belediyesi Atatürk Kitaplı̆̆ 1 Demirbaş no: O.E.824, 60-65). Aynı mektup, Tunahan'a nispet edilen eserde "İsrâ" başlığı ile yer almaktadır (s. 92-96). Bunun yanı sıra Oğuz ile Ahmet Avni Konuk'un Vahdet-i Vücûd ve Vahdet-i Şühûd Münakaşaları ismi bilinmeyen bir müstensih tarafindan istinsah edilmiştir. Eserin kapağında İsmail Fenni Ertuğrul ismi yazdığı için onun istinsah etmiş olması muhtemeldir. İstanbul Büyükşehir Belediyesi Atatürk Kitaplığı Osman Ergin yazmaları O.E.1813, 15.

50 Aslında bizi bu araştırmaya sevk eden de söz konusu ifadeler olmuştur.

51 Çapakçurî nisbesi ile anılan Seyyid Ahmed el-Kürdî 1921'de vefat etmiştir. Kabri, Elazığ'da Harput Ulu Camii bahçesinde bulunmaktadır. http://www.mared.org.tr/Icerik/seyyid-ahmet-\%C3\%A7apak\%-

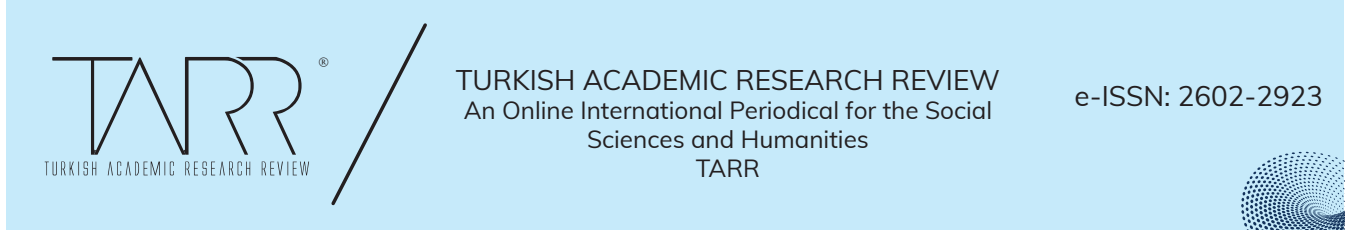


Yani eserin Tunahan'a aidiyetinin kabul edilmesi durumunda onun mürşidinin es-Seyyid Ahmed el-Kürdî el-Hüseynî olması gerekmektedir. Halbuki Tunahan'in silsilesinde bu isimde bir mürşidi yer almamaktadır. Onun Ahmed el-Kürdî ile herhangi bir irtibatı da bulunmamaktadır. Tunahan'ın mürşidi daha önce de belirtildiği gibi Salâhuddîn İbn Mevlânâ Sirâcüddîn (ö. 1910) olarak verilmektedir. $\mathrm{Bu}$ durumun açığa kavuşturulması için başvurduğumuz kişilerden aldığımız cevap Ahmed el-Kürdî isminin aslında gerçek bir isim olmadığı, müsteâr/hayâlî bir isim olduğu şeklindedir. Buna göre Tunahan, yeni rejimin baskı ve takibatına maruz kalmaması için kendi mürşidinin ismini müsteâr olarak kullanmıştır. Fakat bu izah her şeyden önce tarihî gerçekliklerle uyuşmamaktadır. Zira Tunahan'ın mürşidi olan Salâhuddîn'in birkaç defa İstanbul'a geldiği ${ }^{52}$ biliniyor ise de o, bugün Kırgızistan sınırları içerisinde bulunan Oş şehrinde yaşamıştır. Bu durumda Türkiye'de yeni kurulan rejimin Kırgızistan'da yaşayan birine nasıl zarar vereceği sorusunun cevaplanması gerekmektedir. Dahası Salâhuddîn henüz Cumhuriyet kurulmadan 13 sene önce, 1910 yılında vefat etmiştir. ${ }^{53}$ Dolayısıyla ortada kendisine zarar verebilecek bir rejim de henüz mevcut değildir.

Öte yandan es-Seyyid Ahmed el-Kürdî el-Hüseynî, Muhammed İhsan Oğuz'un mürşididir. Oğuz'un Ahmed el-Kürdî ile irtibatı ve ona intisabı, aralarındaki mektuplaşmalar vasıtası ile gerçekleşmiştir. Ahmed el-Kürdînnin Oğuz’a gönderdiği, içerisinde icazetnamenin de bulunduğu dokuz mektup Oğuz'un Tasavvuf Yolunda Manevî Cihad isimli eserinde yayınlanmıştır. ${ }^{54}$

O halde yukarıda verdiğimiz, Süleymanlı Cemaatinin bastığı Mektuplar'da yer alan ifade çok açık ve inkâr edilemez biçimde eserin Oğuz'a ait olduğunu ortaya koymaktadır. Bu ifade aynı zamanda mektupların Tunahan'dan ya da cemaate mensup başka bir kişiden Oğuz'a intikal etmiş olabileceği ihtimalini de ortadan kaldırmaktadır. Zira böyle bir ihtimalin kabul edilmesi durumunda Oğuz'un nasıl olup da Süleymanlı Cemaatinin bastığı Mektuplar'a kendi mürşidinin ismini dahil ettiği sorusuna cevap verilmesi gerekmektedir.

2. Mektuplar ve Bazı Mesâil-i Mühimme isimli eserde "Rahmi Bey’e Yazılan Mektubun Bazı Kısımları” başlığı yer almaktadır (s.119).

Bu başlı̆ga göre söz konusu mektubun "Rahmi Bey” isimli birine yazılmıs olması gerekmektedir. Süleyman Hilmi Tunahan'ın "Rahmi Bey” adında birisine mektup yazdığına dair hiçbir bilgiye ulaşılamamıştır. Söz konusu ismin de müstear bir isim olduğu ya da onun bağlılarından Ramo Amca isimli bir zat olabileceğine yönelik yorumlara ulaştık. Fakat Ramo Amca'nın okuma yazma bilmemesi ve Tu-

C3\%A7uri-hz-2735, erişim: 04.02.2019.

52 Fazilet Neşriyatın yayımladığı Silsiletü'z-Zeheb Silsile-i Sâdât-ı Nakşibendiyye isimli eserde yer alan, Salâhuddîn'in 1908 yılında İstanbul'a geldiğini bildiren ve herhangi bir kaynağa dayandırılmayan bilgi tashihe muhtaçtır. Fazilet Neşriyat Araştırma Heyeti, Silsiletü'z-Zeheb Silsile-i Sâdât-ı Nakşibendiyye, 5. bs., İstanbul: Fazilet Neşriyat, 2017, 332-333. Zira Salâhuddîn'in torunun torunu Madınabonu Mo1dınova, onun bu tarihte İstanbul'a geldiğine dair ellerinde bir delil bulunmadığını ifade etmiştir.

53 Necdet Tosun, "Selâhaddîn Sâkıb", Türkiye Diyanet Vakfi İslâm Ansiklopedisi, (İstanbul: TDV Yay., 2016) Ek-2: 498.

54 Oğuz, M. İhsan, Tasavvuf Yolunda Manevî Cihad, İstanbul: Oğuz Yayınları, 1993, 186-243.

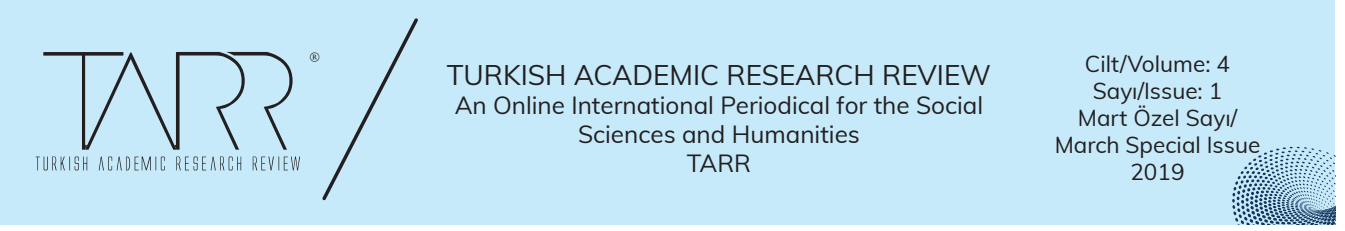


nahan'ın kendisine mektup yazdığına dair hayatında iken kendisinin bir beyanının bulunmaması bu yorumu da geçersiz kılmaktadır.

Diğer taraftan Muhammed İhsan Oğuz'un ihvânı içerisinde, Mektuplar'ın aslını teşkil eden kütüklerin de bir müddet kendisinde bulunduğu, Rahmi Köseoğlu isminde birisi bulunmaktadır. Üstelik Oğuz'un Rahmi Bey'e çok sayıda mektup yazdığ 1 bilinmektedir. Her iki eserde yer alan bir numaralı mektup da Oğuz'un Rahmi Bey'in nispet talebine cevap olarak kaleme aldığı bir mektuptur. Nitekim mektubun muhtevasında yer alan ifadelerden de nispet talebinde bulunulduğu açık bir biçimde anlaşılmaktadır. ${ }^{55}$

Buna göre yine Süleymanlı Cemaatinin bastığı Mektuplar'da yer alan "Rahmi Bey’e Yazılan Mektubun Bazı Kısımları” ifadesi de Mektuplar'ın Oğuz'a aidiyetini kat'î surette ortaya koymaktadir.

3. Mektuplar ve Bazı Mesâil-i Mühimme isimli eserde yer alan "Akreb-i Turuk-i Vusûl: Sohbet” başlıklı mektubun ikinci paragrafının son cümlesi

\section{"Bu husûsât, tarz-1 diğerde bizim Kitâbü Âdâbi'l-Mürîd'imizde mezkûr- dur. Ona da mürâcaatla tafsîlât alınabilir."}

şeklindedir (s. 54).

Tunahan'ın Kitâbü Âdâbi'l-Mürîd isimli bir eseri bilinmezken Oğuz'un Kitâbü Âdâbi'l-Mürî̀în adlı bir eseri mevcuttur. Bu eserin 1971 tarihli daktilo nüshas1 elimizdedir. Söz konusu eserin Oğuz'a ait başka nüshalarının da bulunduğu ve bir kısmını diğer eserleri gibi ihvanından bazı kişilere gönderdiği tahmin edilmektedir. ${ }^{56}$ Aslında bu eser, Tunahan'ın Mektuplar'ında da "Âdâb-1 Zarûriyye" başlığ 1 taşıyan bölümde mefhum ve mana itibarı ile bulunmaktadır. Tunahan'ın hiçbir talebesinden onun bu isimde bir kitap yazdığ 1 da tarafımızca tespit edilememiştir. O halde yukarıdaki ifade de Mektuplar'ın Oğuz'a aidiyetini ortaya koymaktadır.

4. Mektuplar ve Bazı Mesâil-i Mühimme isimli eserde

"Bu mebhasda kaderi ve cebrîlik yapmamalıdır. Eserlerimizde bu umûra müteallik maârifi okuyup anlamalı, mezheb-i vasat ve necât olan Ehl-i sünnet mezhebi dairesi dahilinde mu'tekıd ve âmil olmalidir."

ifadeleri mevcuttur (s. 127).

55 "Mademki siz rızâullâh için mahabbet esâsına müsteniden benim ile arkadaşlığı talep ediyorsunuz ve geri çevrilmemenizi istiyorsunuz, ben de sizden benim için bu arkadaşlığa terettüb eden vazâif ve vecâibin mukaddimât-1 esâsiyesini bildiriyorum. Bunları hüsn-ü telakkî ve idrâke muvaffakiyetinizi Mevlâ'dan dilerim" (Mektuplar ve Bazı Mesâili Mühimme, 12); "Mademki sizinle aramızda nisbet-i mahabbet teessüs edecektir; benden göreceğiniz mukâbele ve hizmet, dâimâ hayât-1 ebediyye ve sermediyeye nâiliyyetinizin mevkûfun ileyhi olan ümûr ve husûsun ifade ve edâsı olacaktır (Mektuplar ve Bazı Mesâili Mühimme, 19) vb. bazı ifadeler Oğuz'un takipçilerinin ifade ettiği gibi karşı taraftan (Rahmi Bey'den) gelen bir intisap talebine cevap niteliği taşımaktadır. Ayrıca Tunahan'ın Mektuplar'ında yer alan "Vâlide-i muhteremenizin dâr-1 âhirete intikali haberini müş'ir olan mektubunuzu bu sabah kemâl-i hüzn ile aldım" (s. 109) cümlesi ile başlayan mektubun, Rahmi Köseoğlu'nun annesinin vefatı üzerine Oğuz'un ona gönderdiği taziye mektubu olduğunu 36 numaralı dipnotta belirtmiştik.

$56 \mathrm{Bu}$ eserin sadeleştirilmemiş asıl nüshasının Taptık'ın kaleme aldığı kütüklerde de mevcut olduğunu Mustafa Bayburtlu bildirmektedir.

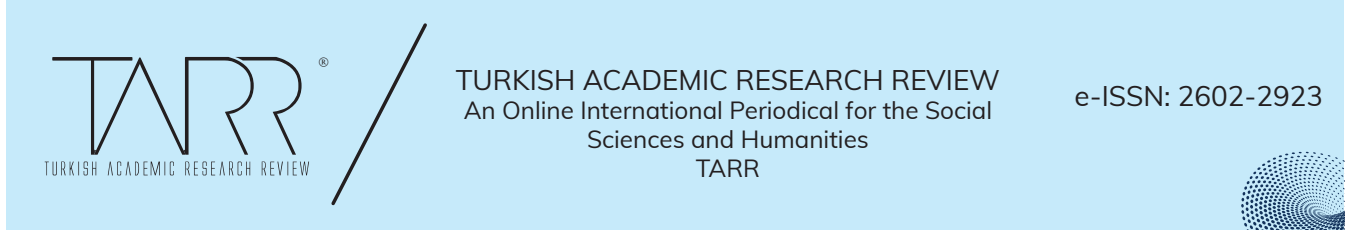


Süleymanlı Cemaatinin bastığı Mektuplar'da yer alan yukarıdaki konuya dair Tunahan'ın herhangi bir eseri bulunmamasına rağmen Oğuz'un ilgili konudan bahseden birkaç eseri bulunmaktadır. Kazâ ve Kader Kitabı ismiyle basılan Kitâbu'lKazâ ve'l-Kader ile İslam Düşüncesinde 7 Önemli Konu ismiyle basılan Fusûl-i Seb'a bunlardan bazılarıdır. ${ }^{57} \mathrm{Bu}$ ifadeler de eserin Oğuz'a aidiyetini ispatlamaktadır.

5. Süleymanlı Cemaati tarafından Risâle-i Kibrît-i Ahmer ismiyle basılan eserde

"Arş- a'lâ ile arş-1 kalbînin siaları, yekdiğerine nispetle olan efdaliyyet ve eşrefiyyetleri meselesi mesâil-i azîme ve gâmizadandır. Burada onların bahsi gayr-i maksud olmakla tahkîk ve tafsîli diğer eserlerimizin mutâlaasına havale edilmiștir."

ifadeleri yer almaktadir (s. 10).

Tunahan'ın yukarıdaki alıntıda bahsedilen konuya ilişkin herhangi bir eseri bilinmezken ${ }^{58}$ Oğuz'un İslâm Tasavvufunda Vahdet-i Vücûd, ${ }^{59}$ Seyru's-Sâlikîn fî Menâzili'l-Ârifin, Şerh-i Makamât ve Istılâhât-ı Sûfiyye ${ }^{60}$ gibi eserlerinde ise konuya ilişkin tafsîlât mevcuttur. O halde bu ifadeler, Risâle-i Kibrît-i Ahmer ismiyle basılan eserin de Oğuz'a aidiyetini ortaya koymaktadır.

6. Risâle-i Kibrît-i Ahmer ismiyle basılan eserde

"Vasl-1 uryân, Kitâb-ı Mir'ât'da yazılıdır" (s. 19)

Her ne kadar bu ifadelerde iyelik zamiri kullanılmamış olsa da Oğuz'un Mir'ât-ı İmâm-ı Rabbânı̂ isimli bir eserinin mevcut olması ve içerisinde "vasl-i uryân"dan bahsedilmesi, yine eserin Tunahan'a değil, Oğuz'a ait olduğunu göstermektedir. ${ }^{61}$ Zira Tunahan'ın bu isimde bir eseri mevcut değildir.

Metinlerin muhtevasından hareketle tespit edilen bu şahıs ve eser isimlerinin bir tarafta "müstear isim" olarak takdim edilmesi ya da açıklanamaması, diğer tarafta ise söz konusu şahıs ve eser isimlerinin gerçek kişilere ve eserlere tetâbuk etmesi, Mektuplar ve Bazı Mesâil-i Mühimme isimli eserin ve İksîr-i Ulûm ve Ma'rifet ile birlikte basılan Risâle-i Kibrît-i Ahmer'in Oğuz'a aidiyetini şüpheye mahal bırakmayacak kesinlikte ispat etmektedir.

57 Bkz. Oğuz, M. İhsan, Kazâ ve Kader Kitabı, İstanbul: Oğuz Yayınları, ts.; Oğuz, M. İhsan, İslâm Düşüncesinde 7 Önemli Konu, Sadeleştirilmiş 2. bs., İstanbul: Oğuz Yayınları, 1993.

58 Burada göz önünde bulundurulması gereken bir husus da Tunahan'ın, tedrîsi, yani dînî ilimleri okutarak ülkenin o dönemde acil olarak ihtiyaç duyduğu dinî hizmetleri ifa edecek hocalar yetiştirmeyi önceleyen metodudur. Sürekli tedrîs ile meşgul olmak, doğal olarak telifi, yani kitap yazma imkanını kısıtlayan bir durumdur. $\mathrm{O}$, dönemin acil ihtiyacını göz önünde bulundurarak bunu “...yazılan ilmî eserleri anlayarak anlatacak ve ilmi satırdan sadra intikal ettirip yaşatacak talebe, yani canlı kitap yetiştirmek..." şeklinde ifade ediyordu.

59 İslâm Tasavvufunda Vahdet-i Vücûd isimli eser ilk defa 1976'da basılmıştır. 1995 yılında sadeleştirilerek ikinci baskısı yapılmıștır.

60 Oğuz'un Seyru's-Sâlikîn fî Menâzili'l-Ârifin ve Şerh-i Makamât ve Istılâhât-ı Sûfiyye isimli eserleri henüz basılmamıştır.

61 Oğuz'un varislerinde bulunan nüsha dışında İstanbul Büyükşehir Belediyesi Atatürk Kitaplığı Demirbaş no: O.E.1174'te bu eserin Osman Ergin tarafindan müellif nüshasından istinsah edilen bir nüshası mevcuttur. Bu konu hakkında 23 numaralı dipnotta bilgi verilmiştir.

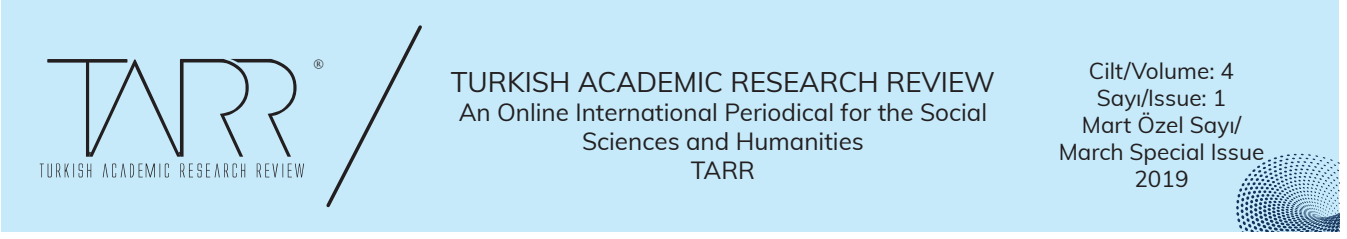


Burada sorulması gereken en önemli soru, söz konusu eserlerin "Nasıl, kim tarafından, ne zaman ve hangi amaçlarla Tunahan'a nispet edildiği ve Oğuz'dan Süleymanlı Cemaatine bu eserlerin nasıl intikal ettiği”dir. Ulaşabildiğimiz bilgiler ışığında şimdi bu sorunun muhtemel cevaplarına geçebiliriz.

\section{Mektuplar ve Kibrît-i Ahmer Süleymanlı Cemaatine Nasıl İntikal Etmiş-} tir?

Burada öncelikle belirtilmesi gereken, Mektuplar ve Kibrît-i Ahmer isimli eserlerin Süleymanlı Cemaatine nasıl, kim vasıtasıyla ve ne zaman intikal ettiğine dair kesin bir bilgiye ulaşamadığımızdır. Zira cemaat içerisinde bu konu ile ilgili araştırma yapan ve metni tenkit gözü ile okuyan; dolayısıyla metnin Tunahan'a ait olduğunu kabul etmeyen bazı kişiler hariç tutulursa cemaat mensupları genel olarak metinlerin ona ait olduğuna inanmaktadırlar. Başka bir ifade ile müntesipler bu meseleyi ilmin konusu olarak değil, inancın konusu olarak görmektedirler. Bundan dolayı da bu meselenin araştırılmasını ve incelenmesini hoş karşılamamakta, konuya ilişkin bilgi taleplerine olumsuz yaklaşmaktadırlar. Eserlerin basımında görev almış cemaat mensubu bazı kişilerin, yukarıda bahsettiğimiz metinlere yönelik sorulara verdikleri tek cevap, cemaatin eski lideri Kemal Kacar'ın kendilerine bu eserlerin Süleyman Hilmi Tunahan'a ait olduğunu söylediği ve onun bu konudaki tanıklığ1nın kendileri için yeterli olduğudur. ${ }^{62}$ Oysa sadece bizim bu makalede göstermeye çalıştığımız metin ve muhtevaya ilişkin bazı unsurların bile göz önünde bulundurulması, üç eserin de Süleyman Hilmi Tunahan'a ait olamayacağını, tam tersine Muhammed İhsan Oğuz'a ait olduğunu açıkça ortaya koymaktadır. Kaldı ki söz konusu eserlerin Tunahan'dan kime/kimlere intikal ettiğine ve basılıncaya kadar nasıl bir seyir izlediğine dair bir sened de ortaya konamamaktadır. ${ }^{63}$ Bunların

62 Burada belirtmemiz gerekmektedir ki söz konusu kişilerin Mektuplar'in Tunahan'a aidiyetini Kemal Kacar'ın bizzat ifade ettiğine yönelik iddialarını doğrulama imkânımız olmamıştır. Kacar'ın yakınında uzun süre bulunmuş bazı isimler, onun bu yönde bir ifadesini kendilerinin duymadıklarını, tam tersine onun, Mektuplar'ın içerisinde Ehl-i sünnet itikadına uygun, faydalı bilgiler bulunduğu gerekçesi ile sadece okunmasını tavsiye ettiğini, Mektuplar'ın daha sonra Tunahan'a nispet edildiğini ifade etmişlerdir. Yukarıda metnini verdiğimiz ses kaydında Kemal Kacar'ın bahsettiği risâlelerin Kibrît-i Ahmer ve İksîr-i Ulûm olması kuvvetle muhtemeldir. Bu yüzden onun, Mektuplar'ı olmasa da bu iki eseri Tunahan'ın kaleme almış olduğunu düşündüğünü rahatlıkla söyleyebiliriz. Ancak Kibrît-i Ahmer ismiyle basılan risâlenin de Oğuz'un Mektuplar'ı içerisinde bulunması ve muhtevasında Oğuz'un başka eserlerine atıflar yapılması, bu eserin de Oğuz'a ait olduğu noktasında bizce hiçbir kuşkuya yer bırakmayacak niteliktedir. Üstelik Taptık'ın istinsah ettiği kütüklerin, cemaat içerisinde Mektuplar'ın ve Kibrît-i Ahmer'in bilindiğini kesin olarak bildiğimiz 1977 ya da 1978 tarihlerinden çok eski tarihli olması da (1930'lu yıllar) bu hususu destekleyen başka bir delildir. Bunun yanı sıra Süleyman Hilmi Tunahan'ın bizzat kendisinden söz konusu eserlerin kendisine ait olduğunu bildiren hiçbir nakle de ulaşılamamıştır. İfade edilmesi gereken bir başka husus ise Süleyman Hilmi Tunahan'ın önde gelen ve bugün hayatta olan bazı talebelerinin, söz konusu eserlerin ona aidiyetini kabul etmedikleri, ancak cemaat içerisinde uzun yıllardır yerleşik olan bu durumu reddetmelerinin, kendilerinin cemaatten dışlanmasına sebep olacağı için bu hususu yakın dostları hariç kimse ile paylaş(a)madıklarıdır. Bu durum, gruptan dışlanma korkusunun ve psikolojisinin cemaat(ler) içerisinde ne kadar etkin olduğunu göstermesi açısından kayda değerdir.

63 Konuya ilişkin bizim, makale yayımlanmadan önce eserler ile ilgili ortaya attığımız sorulara cevap vermeye çalışan bazı kişiler, makaleye reddiye yazacaklarını, ellerinde eserlerin Süleyman Hilmi Tunahan'a ait olduğunu gösteren delillerin bulunduğunu ifade etmelerine rağmen ortaya attığımız sorulara cevap verememişlerdir.

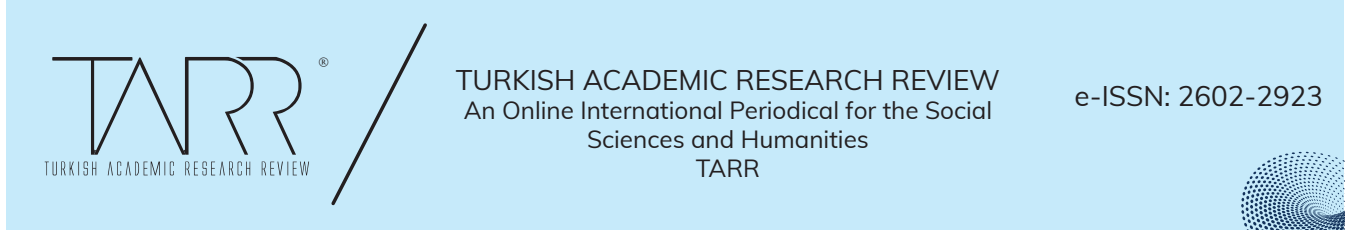


yanı sıra Tunahan'ın bizzat kendisinden, söz konusu eserleri kendisinin kaleme aldığına dair bir nakil de bulunmamaktadır.

Oğuz'un mektuplarını baskıya hazırlayan Mustafa Bayburtlu'nun ve Oğuz'un varislerinin bildirdiğine göre Mektuplar ve Kibrît-i Ahmer isimli risâle, çok yüksek ihtimalle önceden onun bağlılarından olan Vehbi Bilimer vasıtasıyla Süleymanlı Cemaatine intikal etmiş olmalıdır. Zira Oğuz'un, Mektuplar ve Bazı Mesâil-i Mühimme ismiyle cemaatin bastığı eserde de ismi geçen Rahmi Köseoğlu'nun iş ortağ1 olan Vehbi Bilimer'e mektuplar gönderdiği bilinmektedir. Daha sonra Oğuz'un, içerisinde Hz. Muâviye ile ilgili bazı görüssleri bulunan Miftâhu's-Seâde isimli kitabındaki bazı görüsslerine muttali olunca, Bilimer, cemaatine devam ettiği caminin imamina onun Hz. Muâviye hakkındaki görüşlerinden bahseder. Süleyman Hilmi Tunahan ile bir irtibatı bulunduğu tahmin edilen cami imamı, bu mesele hakkında Ehl-i sünnet alimlerinin çoğunluğunun görüşünün aksi istikamette olduğu konusunda Bilimer'i ikna eder. Onu başka bazı hocalar ile de görüştürür. Neticede Vehbi Bilimer, Oğuz ile yıllar süren irtibatını ve ona olan intisabını sonlandırır. ${ }^{64}$ Hatta Vehbi Bilimer Oğuz'a ((Sizi Ehl-i sünnet itikadına davet ediyorum!” diye bir mektup da yazar. Vehbi Bilimer irtibatı kesse de Oğuz, ona birkaç mektup daha yazar, ancak o irtibatı kesmede israr edince "Alakayı kesseniz de uhuvvet-i diniyyemiz bakidir” dediği bir mektup daha gönderir. Bayburtlu ve Oğuz'un varislerinin kanaatlerine göre Bilimer'de gerek kendisine gerek ortağ Rahmi Köseoğlu'na gönderilmiş Oğuz'un çok sayıda mektubu bulunmaktadır. İște Süleymanlı Cemaatine intikal eden mektuplar ve risâleler Vehbi Bilimer'in elinde bulunanlar

64 Nitekim bu konuya dair Recep Kabakçı tarafından Emin Saraç ile yapılan ve İlim Yayma Cemiyeti Bülteni 'nde yayımlanan bir röportaj şu şekildedir:

“Recep Kabakçı: Hocam Ali Haydar Efendi'nin evinde de Cemiyet'imizin ileri gelenleri bir araya gelmişler. Onların hangileri olduklarını biliyor musunuz?

Emin Saraç: Mesela Vehbi Bilimer. Vehbi Bey çok gözü yaşlı bir insandı. Allahu Ekber. Öyle bir insandı. Erzurumludur, Narmanlıların damadıdır. Kendisi kurmay subaylıktan tekaüd bir vaziyetteydi. Abimle aralarında vuku bulan şu hadiseyi de anlatmak isterim. Vehbi Bilimer Kastamonu'da bir şeyh varmış, ona tabii olmuş [Muhammed İhsan Oğuz'u kastediyor] ve yıllarca evrad-u ezkarı çekmiş. Vehbi Bey bazı dini hassasiyetlerinden dolayı oraya alakasını kesmiş. (Hocasının Hz. Muaviye hakkındaki fikirleri bu kopmaya sebep olmuş.) [Parantez içindeki kısım bültende bulunmamakta fakat internet kaynağında bulunmaktadır] Ama daha sonra içine vesvese-i şeytani düşmüsş. "Bu kadar evrad-u ezkarın var, bunlar n'olacak” diye. O sıradalar abim, Karaköy ... Camiisi imamı, bir rüya görmüş. Namazı kılıyor, yatıyor ve bu rüyayı görüyor. Vehbi Bey'in Maslak’taki evine gidiyor, bakıyor ki eşyası arabada taşınacak vaziyette. Abim neden taşındığını sormuş. Abime, Vehbi Bey'in sahabe efendilerimizin birinin akrabası olduğunu, sahabe efendimize ait bir yalının Vehbi Bey'e miras kaldığını, Vehbi Bey'in de şimdi o yalıya taşındığını söylemişler. Neyse Abim uyanıyor ve Vehbi Bey'i tanıdığı için hemen Vehbi Bey'e telefon açıyor. Vehbi Bey’e gördügü rüyayı olduğu gibi anlatıyor. Vehbi Bey çok şaşırıyor. Evin adresini istiyor. "Evden ayrılma hemen geliyorum" diyor. Gidiyor abimin evine gözyaşları içinde hem teşekkür ediyor hem sarılıyor. Öylece gönlü de rahata eriyor. [Hz. Muaviye radıyallahu anh uğruna şeyhinden ayrılmakta isabet ettiğini anlıyor.] (Köşeli parantez içi internet kaynağında mevcut) Vehbi Bey hastalanmıştı, zaten kanser vardı kendisinde. Ama bize o zaman bile hep ümitle konuşmuştu. Bizim göremediğimiz güzel ve hayırlı günleri siz göreceksiniz derdi. Yatağa düşmesinden kısa bir süre sonra da zaten ahirete irtihal etti.

Ahmet Çiftçi [İnternet kaynağında Çıkrıkçı] de onlardan birisidir. O da Balıkesirli. Bu zat da bize hep ümitvar konuşurdu. Bu batıl zail olucudur derdi. "Biz gittiğimiz zaman siz döndüğünüzde Türkiye daha iyi olacak” derdi. Dediği gibi de her zaman daha iyiye gidiyor. Sizin de İlim Yayma Cemiyeti olarak bu gidişatta iyi bir hizmettesiniz. Böyle devam edersiniz inşallah.” Kabakçı, Recep, İlim Yayma Cemiyeti Bülteni, (Emin Saraç ile röportaj) Bahar 2011, sayı 23, 16; https://www.dunyabizim.com/alinti/emin-sarac-hocaefendi-ile-hasbihl-h7065.html, erişim: 11.01.2019.

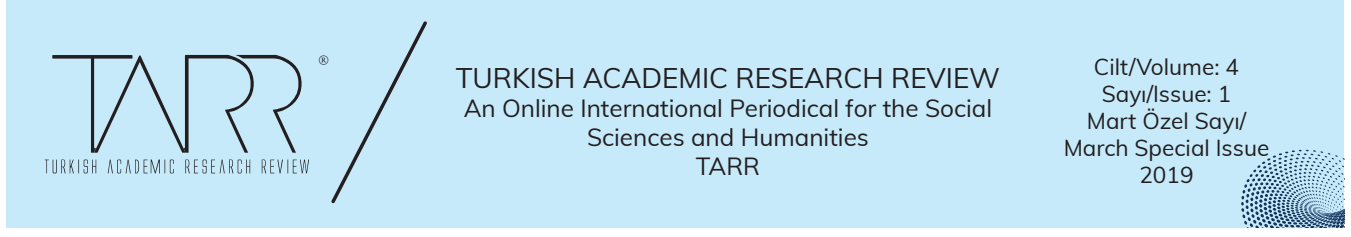


olmalıdır. Bayburtlu'nun kanaatine göre Bilimer 1970 yılında vefat ettiğine göre mektupların intikal vakti de bu yıldan öncedir. Mektupların intikal tarihi büyük ihtimalle de 1965-70 yılları arasıdır. ${ }^{65}$ Nitekim bu tarih, bizim Süleymanlı Cemaati içerisinde mektupların bilindiğini tespit ettiğimiz en eski tarih olan 19771978 yıllarına yakın bir tarihtir. Araştırmamız boyunca Süleyman Hilmi Tunahan'in vefat tarihi olan 1959 senesi ile 1977 senesi arasinda mektupların cemaat içindeki seyir ve intikaline ilişkin hiçbir bilgiye ulaşılamamıştır. ${ }^{66}$

Mektuplar'in ve Kibrît-i Ahmer'in Süleymanlı Cemaatine intikaline dair yukarıda bahsettiğimiz hadisenin ve tarihin güçlü bir tahmin olduğunu söylemekle birlikte kesinliğinden söz etmemizin mümkün olmadığını bir kere daha hatırlatmakta fayda vardır. Ancak Oğuz'un varisleri ve sevenleri, söz konusu eserlerin intikaline ilişkin başka hiçbir ihtimal bilmemektedirler. Rahmi Köseoğlu'nun Vehbi Bilimer'in iş ortağı olduğu akılda tutulursa Süleymanlı Cemaatinin bastığı Mektuplar'da "Rahmi Bey’e Yazılan Mektubun Bazı Kısımları" başlığı ile verilen mektubun da Vehbi Bilimer'e nasıl intikal ettiği izah edilebilir. Yani Rahmi Bey'e yazılan mektuplara iş ortağı olmaları itibarı ile Vehbi Bilimer'in de vakıf olduğu, hatta bir nüshasını almış olabileceği kolaylıkla söylenebilir. Zira elimizdeki bilgilere göre Rahmi Bey'e yazılan mektubun cemaate intikali hakkında başka bir açıklama yapmak mümkün değildir.

Öte yandan Bilimer'in ve bazıları Oğuz'un müntesiplerinden olan İlim Yayma Cemiyeti kurucularından birçoğunun Tunahan ve Süleymanlı Cemaati ile yakın ilişki içerisinde oldukları da bilinmektedir. Cemaatin çıkardığı Ufuk gazetesinin 1978 tarihli 462. sayısında Tunahan'in talebelerinden Mehmed Bozkurt ile yapılan bir röportajda "O senelerde vuku bulan bir hatıranızı da anlatır mısınız?" sorusuna şöyle cevap vermiştir:

"1954 senesi Haziran ayı idi. Bir gün merhum Ali Dayı geldi. Bana Efendi Hz. seni istiyor dedi. Beraber misafirhaneye gittik. Efendi Hz. Bana dedi ki:”

'Oğlum Hafız Mehmed! İlim Yayma Cemiyeti yöneticileri gelecekler. Derslerine iyi çalışsınlar, temizliğe de dikkat etsinler””

Bu ifadelere göre Süleyman Hilmi Tunahan, henüz birkaç yıl önce, 1951'de kurulmuş olan, aralarında Vehbi Bilimer'in de bulunduğu İlim Yayma Cemiyeti'nin yöneticileri ile tanışmaktadır ve onlarla yakın ilişki içerisindedir. ${ }^{67}$ Kendisini ziyarete gelen kişilerin içerisinde İlim Yayma Cemiyeti’nin kurulmasında aktif rolü bulunan Vehbi Bilimer'in de bulunması kuvvetle muhtemeldir. Bu durum, Mektuplar'ın ve Kibrît-i Ahmer'in Tunahan'ın hayatında iken ona intikal etmiş olabileceği ihtimalini akla getirse de bu ihtimali destekleyen herhangi bir veriye ulaşmış

65 Zira Vehbi Bilimer'in Oğuz ile alakayı kesmesine neden olan Miftâhu's-seâde isimli eseri 1964 yılında yazılmış ve ilk baskısı 1968 yılında yapılmıştır.

66 Araştırmamız sırasında her iki taraftan çok sayıda kişi ile mülakatlar gerçekleştirilmiş olup ayrıca çok sayıda belgeye ulaşılmıştır. Hacmi artırmamak için makalede yer verilemeyen bütün bilgi ve belgeleri detaylı bir kitap çalışmasına ertelediğimizi bildirmek isteriz.

67 Nitekim gazetede yer alan röportaj dışında o dönemi müşahede etmiş çok sayıda kaynaktan da Tunahan'ın İlim Yayma Cemiyeti kurucuları ile olan yakın dostluğunu ve irtibatını teyit etmiş bulunuyoruz.

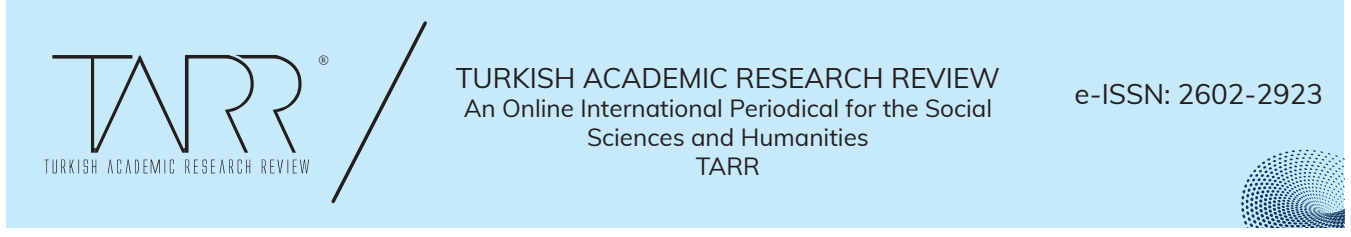


değiliz. Vehbi Bilimer'in cemaatle yakın ilişkisini gösteren bir başka husus da şudur: Bilimer 1964 yılında yani Tunahan'ın vefatından 5 yıl sonra, onun torunları Mehmet Beyazıt Denizolgun ${ }^{68}$ ve Arif Ahmet Denizolgun'un ${ }^{69}$ Çamlıca'daki köşkte düzenlenen sünnet merasimlerine katılmıştır. ${ }^{70}$ Söz konusu hadise Bilimer'in cemaat ile olan yakın ilişkisini göstermesi bakımından önemlidir. Bu tarih aynı zamanda Bilimer'in Oğuz ile olan irtibat ve intisabını sonlandırmasına sebep olan Miftâhu's-Seâde isimli eserin yazıldığ 1 tarihtir.

Elimizdeki bilgilere göre Süleymanlı Cemaati ile Muhammed İhsan Oğuz arasında irtibat noktası olabilecek en kuvvetli kişilerden biri Vehbi Bilimer'dir. Ancak Tunahan'ın, Oğuz'un ihvânından başka kişiler ile de irtibatı bulunmaktadır. Örneğin, Tunahan'in talebe okutma hizmetlerine maddi destek sağlayan, hatta bir ara Çamlıca'da bulunan köşkünü de talebelerin okuması için tahsis ettiği belirtilen ${ }^{71}$ Konya -Lezzet- Lokantası sahibi Mustafa Doğanbey de bu isimlerden biridir. ${ }^{72}$ Doğanbey, Oğuz'a intisabı bulunan ve Süleymanlı Cemaati tarafından da yardımları sebebiyle yakından tanınan biridir. Onun, okumaya ve kitaplara çok düşkün olduğu ve içinde el yazmaları da bulunan geniş kütüphanesini cemaate bağışladığ ve bu kitapların bir müddet cemaatin İstanbul Bakırköy'de bulunan Kartaltepe Yurdu'nda kaldığı bilinmektedir. ${ }^{73}$ Oğuz'a ait eserlerin, Doğanbey'in kitapları arasında cemaate intikal etmiş olması da muhtemeldir. Ancak bu ihtimali destekleyecek bir bilgiye de ulaşamadığımızı belirtmemiz gerekmektedir.

Süleyman Hilmi Tunahan'ın Beyazıt ve Arpacılar camiinde verdiği vaazlardan sonra zaman zaman Sirkeci ve Eminönü'nde bulunan bazı dostlarının iş yerine uğrayıp sohbet ettiği bilinmektedir. Refik Bürüngüz, Mustafa Doğanbey, Süleyman Kuşçulu, Mehmet Üretmen bu kişilerden bazılarıdır. ${ }^{74}$ Sayılan bütün isimler hem İlim Yayma Cemiyeti ve Vehbi Bilimer ile hem de İhsan Oğuz ile yakın irtibatı bulunan kişilerdir.

68 Mehmet Beyazıt Denizolgun, Adalet ve Kalkınma Partisi Kurucular Kurulu Üyesidir. TBMM 22. ve 23. dönem İstanbul milletvekilliği yapmıştır.

69 Arif Ahmet Denizolgun, 4 Ağustos 1998-11 Ocak 1999 tarihleri arasında Ulaştırma Bakanlığ ve 20. dönem Antalya milletvekilliği yapmıştır. Önceki lider Kemal Kacar'ın 17 Haziran 2000'de vefatından sonra kendisinin vefat tarihi olan 8 Eylül 2016 tarihine kadar cemaatin liderliğini sürdürmüştür.

70 Bu bilgi, söz konusu merasimde Denizolgun kardeşlerin kirveliğini yapan Mustafa Akkoca'dan alınmıştir.

71 Reşat Öngören, “Tunahan, Süleyman Hilmi”, Türkiye Diyanet Vakfı İslâm Ansiklopedisi, (İstanbul: TDV Yay., 2012), 41: 376.

72 Mustafa Doğanbey’in aktif bir kişiliğe sahip olduğu ve lokantasının o dönemde pek çok kesimi bir araya getiren bir merkez işlevi gördüğü anlaşılmaktadır. Nitekim Emin Saraç’ın bildirdiğine göre İlim Yayma Cemiyeti'nin kurulmasını o teklif etmiştir. "Mustafa Doğanbey Konya Lokantasının sahibidir. Hatta İmam Hatip Mektebi kurulunca, bunu takviye edecek bir de kurumumuz olsun diye teklif eden o olmuştur. İlim Yayma Cemiyeti'nin toplantıları, daha kendi merkezi yokken, onun lokantasının üstünde yapılırdı. Daha sonra İbnül Emin Mahmut Kemal'in konağına geçti” Kabakçı, Recep, İlim Yayma Cemiyeti Bülteni, (Emin Saraç ile röportaj) Bahar 2011, sayı 23, 18. Ufuk gazetesinde Mehmed Bozkurt ile yapılan röportajda belirtildiğine göre Süleyman Hilmi Tunahan'ı ziyarete gelen İlim Yayma Cemiyeti yöneticilerinden biri de Mustafa Doğanbey'dir.

73 Bu kitapların akıbeti hakkında herhangi bir bilgiye ulaşılamamıştır.

74 Tayyar Altıkulaç'ın Prof. Dr. Bekir Topaloğlu'na dayandırarak naklettiğine göre Süleyman Hilmi Tunahan, Kastamonulu iş adamı Ata Kulaksızoğlu'nun Sultanhamam'daki mağazasında Prof. Dr. Numan Kurtulmuş'un babası İsmail Niyazi Kurtulmuş ve yanındaki heyet ile de görüşmüştür. Altıkulaç, Tayyar, Zorluklarl Aşarken II. 2. bs., İstanbul: Ufuk Yayınları, 2012, 734.

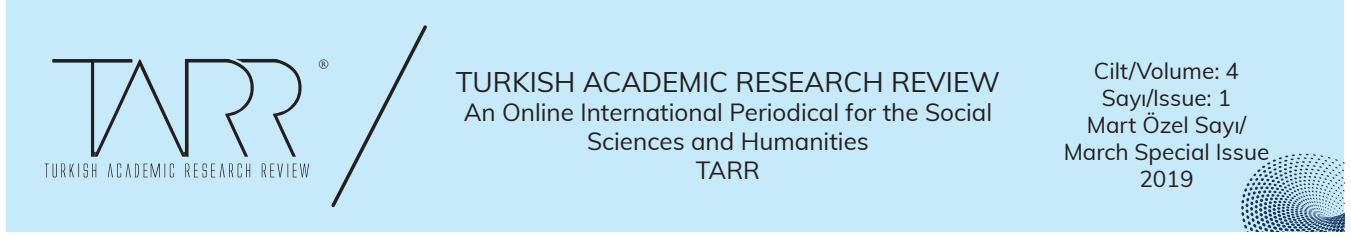




\section{SONUÇ}

Mektuplar ve Bazı Mesâili Mühimme, Risâle-i Kibrît-i Ahmer, Risâle-i İksîr-i Ulûm ve Ma'rifet isimleriyle Süleymanlı Cemaati tarafından basılan ve okunan eserlerin hem muhtevasında bulunan bazı ifadeler, hem de eserlerin intikal süreci ile ilgili ulaşılan metin dışı bilgiler, üç eserin de Muhammed İhsan Oğuz'a ait olduğunu kesin surette ortaya koymaktadır. Yaşadığı dönemde söz konusu eserlerin kendisine ait olduğuna yönelik Süleyman Hilmi Tunahan'ın hiçbir ifadesi bulunmazken sonraki süreçte eserlerin ona nispet edildiği anlaşılmaktadır.

Bu eserlerin Süleyman Hilmi Tunahan'a ait olmadığı halde ona kasten mi yoksa sehven mi isnad edildiği yahut isnad edilme sebebi ile ilgili pek çok yorum yapılması mümkün olmakla birlikte bu konuda şimdilik kesinlik arz edecek bir bilgiye sahip değiliz. Ancak en azından bundan sonra söz konusu isnadın düzeltilmesi hem ilmî emanete, hem de bu iki mühim ismin hukukuna riayet adına önemlidir. Zira Muhammed İhsan Oğuz'un oğlu Abdülhalik Muhammed Oğuz, eserlerin muhtevasına vâkıf olunmasının memnuniyet verici olduğunu, fakat hakikatin de bilinmesini arzu ettiklerini ifade etmişlerdir.

İlginç olan, Mektuplar ve Bazı Mesâili Mühimme ile Kibrît-i Ahmer ismiyle basılan eserlerin muhtevasında Süleyman Hilmi Tunahan'a ait olamayacağını açıkça ortaya koyan ve bir kısmını göstermeye çalıştığımız ifadelere, cemaat içerisinden hiçbir itirazın gelmemiş olmasıdır. Gerçi son yıllarda cemaat içerisinde, eserlerin Süleyman Hilmi Tunahan'a değil, Muhammed İhsan Oğuz'a ait olduğunu fark eden bazı kimseler olmuştur. Fakat söz konusu kişiler çeşitli sebeplerden dolayı bu duruma ya itiraz edememişler ya da itirazları dikkate alınmamıştır. ${ }^{75}$ Aslında Tunahan'in bugün hayatta olan talebelerinden birçoğunun, eserlerin ona nispet edilmesini kabul etmedikleri, fakat uzun yıllardır cemaat içerisinde yerleşik olan bu durumu reddetmelerinin, kendilerinin cemaatten dışlanmalarına sebep olacağını düşündükleri için bu kanaatlerini yüksek sesle ifade etmekten kaçındıkları gözlemlenmektedir.

\section{KAYNAKÇA}

Abdurrahman Memiş, "Oğuz, Muhammet İhsan”, Türkiye Diyanet Vakfi İslâm Ansiklopedisi, (İstanbul: TDV Yay., 2007), 33: 321-322.

Abdülmecîd b. Muhammed Hânî, el-Hadâiku'l-verdiyye fî hakẩiki ecillẩ' n-Nakşibendiyye, 2. bs., (Erbil: Dâru ârâs li't-tıbâ'a ve'n-Neşr, ts.) Nşr: Şâhvân Kerkûkî.

Akgündüz, Ahmed. Arşiv Belgeleri Ișlğında Silistre’li Süleyman Hilmi Tunahan. İstanbul: Osmanlı Araştırmaları Vakfı, , 1997.

Akgündüz, Ahmed. Tabular Yıkıllyor-2. 7. bs., İstanbul: Osmanlı Araştırmaları Vakfı, 2007.

Altıkulaç, Tayyar. Zorlukları Aşarken II. 2. bs., İstanbul: Ufuk Yayınları, 2012.

75 Eserlerin Süleyman Hilmi Tunahan'a ait olmadığını fark eden ve ona nispet edilmesine itiraz yöneltenlerden biri Ağustos 2018'de geçirdiği kalp krizi sonucu vefat eden ve cemaatte çeşitli görevler yapan Ali Ak'tır. 1977-1980 arasında 16. yasama dönemi milletvekilliği ve müftülük görevlerinde bulunmuştur.

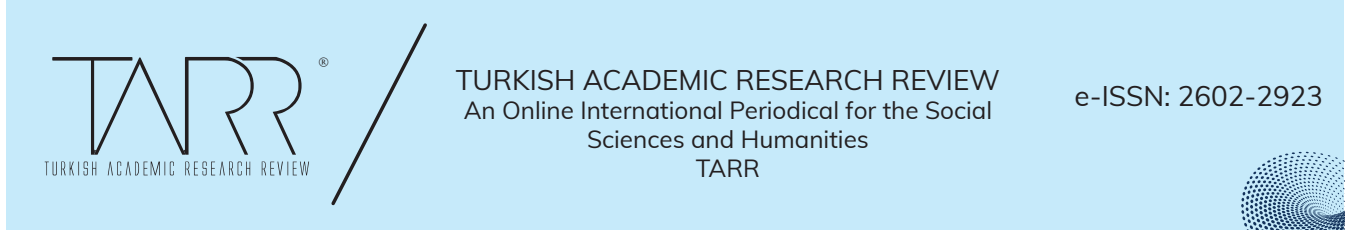


Bayram Kusursuz, Ahmet Avni Konuk'un Vahdet-i Vücûd Müdâfaası. Yüksek Lisans Tezi, Marmara Üniversitesi, 2003.

Dedeoğlu, Abdülkadir. Silsile-i sâdât-ı Nakşibendiyye-i aliyye, 2. bs., İstanbul: Osmanlı Yayınevi. ts.

Emre, Mehmed. Üstâdrm Süleyman Hilmi Tunahan ve Hâtrralarrm. 3. bs., İstanbul: Erhan Yayınları, 2003.

Fazilet Neşriyat Araştırma Heyeti. Silsiletü'z-Zeheb Silsile-i Sâdât-ı Nakşibendiyye, 5. bs., İstanbul: Fazilet Neşriyat, 2017.

Hocazâde Ahmed Hilmi. Hadîkatü'l-evliyâ (Veliler Bahçesi, Tercüme). İstanbul: Osmanlı Yayınevi, 1979.

Hocazâde Ahmed Hilmi. Hadîkatü'l-evliyâ. İstanbul: 1318.

İmâm Rabbânî, Ebü'l-Berekât Ahmed b. Abdilehad b. Zeynilâbidîn el-Fârûkî es-Sirhindî, Mektûbât. İstanbul: İhlâs Vakfi, 1423/2002.

Kabakçı, Recep. İlim Yayma Cemiyeti Bülteni. (Emin Saraç ile röportaj) Bahar 2011, sayı 23.

Mektuplar ve bazı mesâil-i mühimme. (Süleyman Hilmi Tunahan'a nispet ediliyor). yy., ts.

Moıdınova, Madınabonu. Sâkıb Salahaddîn'in Dîvân'ı ve Tasavvufî Görüşleri. Yüksek Lisans Tezi, Uludağ Üniversitesi, 2018.

Mustafa Kara, "Hocazâde Ahmed Hilmi", Türkiye Diyanet Vakfı İslâm Ansiklopedisi, (İstanbul: TDV Yay., 1998), 18: 207.

Mustafa Şevkî Binbîn-Mustafa Tûbâ. Mu'cemü mustalâhâti'l-mahtûti'l-Arabî, 3. bs., Merakeș: el-Hizânetü 'l-Haseniyyeti'r-Ribât, 2005.

Necdet Tosun, "Selâhaddîn Sâkıb", Türkiye Diyanet Vakfı İslâm Ansiklopedisi, (İstanbul: TDV Yay., 2016) Ek-2: 498.

Oğuz, M. İhsan. (Müstensih: Osman Nuri Ergin). İstinsâh Tarihi: 20 Kânûn-1 Evvel 1932, “İhsan Bey'in İzmirli İsmail Hakkı Bey'e Bir Mektubu”, İstanbul Büyükşehir Belediyesi Atatürk Kitaplığı, Demirbaş no: O.E.824, s. 60.

Oğuz, M. İhsan. İslâm Düşüncesinde 7 Önemli Konu. Sadeleștirilmiş 2. bs., İstanbul: Oğuz Yayınları, 1993.

Oğuz, M. İhsan. İslâm Tasavvufunda Vahdet-i Vücûd. İstanbul: 1976.

Oğuz, M. İhsan. Kazâ ve Kader Kitabı. İstanbul: Oğuz Yayınları, ts.

Oğuz, M. İhsan. Kitâbü Âdâbi'l-Mürîdîn. (Henüz basılmamış daktiloda yazılmış nüsha). Kastamonu: 1971.

Oğuz, M. İhsan. Mir'ât-ı İmâm-ı Rabbânî. (Müstensih: Osman Nuri Ergin). İstinsâh Tarihi: 1 Şubat 1932, İstanbul Büyükşehir Belediyesi Atatürk Kitaplığ1 Demirbaş no: O.E.1174.

Oğuz, M. İhsan. Muhammed İhsan Oğuz'dan Mektuplar-I. 2. bs., İstanbul: Oğuz Yayınları, 1994.

Oğuz, M. İhsan. Muhammed İhsan Oğuz'dan Mektuplar-II. 2. bs., İstanbul: Oğuz Yayınları, 1994.

Oğuz, M. İhsan. Saadet Anahtarı. (Orijinal ismi: Miftâhu's-seâde), İstanbul: Oğuz Yayınları, 2017.

Oğuz, M. İhsan. Seyru's-sâlikîn fî menâzili'l-ârifin. (Henüz basılmamış).

Oğuz, M. İhsan. Şerh-i makamât ve ıstılâhât-ı sûfiyye. (Henüz basılmamış).

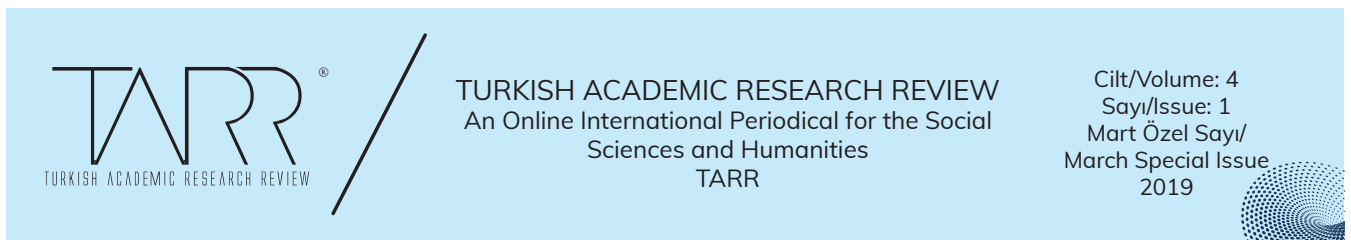


Oğuz, M. İhsan. Tasavvuf Yolunda Manevî Cihad. İstanbul: Oğuz Yayınları, 1993.

Osman Türer, "Hânî, Abdülmecîd b. Muhammed", Türkiye Diyanet Vakfi İslâm Ansiklopedisi, (İstanbul: TDV Yay., 1997), 16: 29-30

Reşat Öngören, "Tunahan, Süleyman Hilmi”, Türkiye Diyanet Vakfı İslâm Ansiklopedisi, (İstanbul: TDV Yay., 2012), 41: 375-377.

Risâle-i iksîr-i ulûm ve ma'rifet. (İsimsiz, Süleyman Hilmi Tunahan'a nispet ediliyor), Şirket-i Mürettibiyye Matbaası, 1330. (Risâle-i kibrît-i ahmer ile birlikte basılmış, Kapakta yer alan basım yeri ve yılı gerçek değil).

Risâle-i kibrît-i ahmer. (İsimsiz, Süleyman Hilmi Tunahan'a nispet ediliyor). Şirket-i Mürettibiyye Matbaası, 1330 (Kapakta yer alan basım yeri ve yılı gerçek değil).

Şaban Sitem Bölükbaşı, "Süleyman Efendi Cemaati”, Türkiye Diyanet Vakfı İslâm Ansiklopedisi, (İstanbul: TDV Yay., 2012), 41: 377.

Taptık, Hayri. (Muhammed İhsan Oğuz'un mektuplarının ve bazı eserlerinin kaydedildiği “Kütük” tabir edilen defterler). Muhammed İhsan Oğuz Vakfı'nda, Kastamonu.

Târık Abdülcelil es-Seyyid. el-Harekâtü’l-İslâmiyye fî Türkiye el-muâsıra. Mısır: Cevâdü’şşark li’n-neşr ve't-tevzî̀, ts.

Tunahan, Süleyman Hilmi, Kur'ân Harf ve Harekeleri. İstanbul: Fazilet Neșriyat, ts.

Ufuk, (Haftalık Siyasî Gazete), 15 Haziran 1979, sayı: 508.

Ufuk, (Haftalık Siyasî Gazete), 6 Eylül 1978, sayı: 474.

Ufuk, (Haftalık Siyasî Gazete), 9 Kasım 1977, sayı: 431.

Vahdet-i Vücûd ve Vahdet-i Şühûd Münakaşaları. (Müstensih bilinmiyor, kapağında İsmail Fenni Ertuğrul yazısı var), Osman Ergin yazmaları Demirbaş no: O.E.1813, İstanbul Büyükşehir Belediyesi Atatürk Kitaplığı.

Yeğin, Önser. Süleyman Hilmi Tunahan ve Tasavvufî Şahsiyeti. Lisans Bitirme Tezi, Dokuz Eylül Üniversitesi, 1996.

\section{INTERNET KAYNAKLARI}

(https://dunyasozluk.com/baslik/\%C5\%9Firket-i+m\%C3\%BCrettibiye+matbaas\%C4 \%B1), (erişim: 11.01.2019).

(http://www.mared.org.tr/Icerik/seyyid-ahmet-\%C3\%A7apak\%C3\%A7uri-hz-2735), (erişim: 04.02.2019).

(https://iyc.org.tr/kurucularimiz ), (erişim: 11.01.2019).

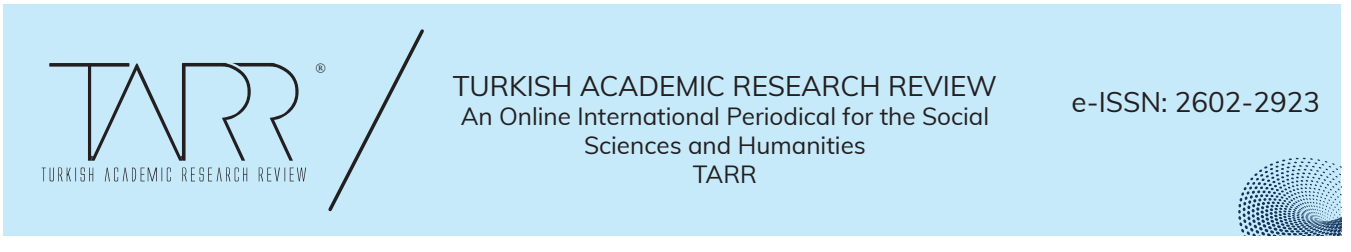

